\title{
Revision of the genus Nastanthus (Calyceraceae)
}

\section{Revisión del género Nastanthus (Calyceraceae)}

\author{
Lucio Zavala-Gallo, Silvia Denham \& Raúl Pozner \\ Instituto de Botánica Darwinion (CONICET y ANCEFN), Casilla de correo 22, B1642HYD San Isidro, Buenos Aires, \\ Argentina. \\ Izavala@darwin.edu.ar
}

\begin{abstract}
The nomenclatural revision of 51 names previously published, combined or synonymyzed under the genus Nastanthus (Calyceraceae) is presented. Six species are recognized with correct names and new synonyms established. The nomenclature of Nastanthus ventosus, Nastanthus scapigerus and Nastanthus compactus is updated, giving a total of 45 synonyms. Lectotypes for Boopis caespitosa, Boopis scapigera, Boopis spathulata, Nastanthus laciniatus, Boopis araucana, Calycera ventosa, Nastanthus pinnatifidus and Boopis breviflora are here designated. A map with the geographic distributions, complete species descriptions, corrected illustrations, and a new key to accepted species of Nastanthus, are included.
\end{abstract}

KeYwords: Calyceraceae, Nastanthus, taxonomy.

\section{RESUMEN}

Se presenta la revisión nomenclatural de 51 nombres publicados, combinados o sinonimizados bajo el género Nastanthus (Calyceraceae). Se reconocen seis especies, estableciendo los nombres correctos y sinónimos nuevos. Se actualizó la nomenclatura de Nastanthus ventosus, Nastanthus scapigerus y Nastanthus compactus, con un total de 45 sinónimos. Se designaron lectotipos para Boopis caespitosa, Boopis scapigera, Boopis spathulata, Nastanthus laciniatus, Boopis araucana, Calycera ventosa, Nastanthus pinnatifidus y Boopis breviflora. Se incluyeron, además, un mapa de distribución geográfica, descripciones completas, ilustraciones corregidas y una clave nueva para las especies aceptadas de Nastanthus.

Palabras clave: Calyceraceae, Nastanthus, taxonomía.

\section{INTRODUCTION}

The family Calyceraceae includes 54 small herbs or subwoody plants species, annuals or perennials, endemic to southern South America (southern Brazil, Bolivia, Paraguay, Uruguay, Chile and Argentina; Chiapella 1999a, 1999b, Zanotti \& Pozner 2008). Most species grow in arid Andean or Patagonian habitats; a few species inhabit eastern, more humid environments, and only one grows in Malvinas (Falkland) Islands (Chiapella 1999a, 1999b; Zanotti \& Pozner 2008). Six genera have been distinguished within Calyceraceae: Acicarpha Juss. (5 species from Argentina, Bolivia, Brasil, Perú and Uruguay); Boopis Juss. (13 species from Argentina and Chile); Calycera Cav. (14 species from Argentina, Bolivia and Chile); Gamocarpha DC. (6 species from Argentina and Chile); Moschopsis Phil. (7 species from Argentina and Chile) and Nastanthus Phil. (9 species from Argentina and Chile). About $90 \%$ of the species grow along the Andes of Argentina and Chile (Zanotti \& Pozner 2008). The most complete information on systematics and taxonomy of Calyceraceae was published by Pontiroli (1963), Chiapella (1999a, 1999b), Galvão Magenta \& Pirani (2002), Hellwig (2007), Zanotti \& Pozner (2008), and literature therein.

Calyceraceae morphology deserves an exhaustive reevaluation. Some contributions have been published during the last 20 years, and these new data confirm a major problem with this family: the lack of sharp boundaries among genera. Reitz (1988) was one of the first authors to suggest the synonymy among Boopis, Gamocarpha and Nastanthus due to poor morphological differences. The palynological results published by Hansen (1992) showed at least two main pollen morphologies in the family, which were not uniform within genera. According to Carlquist \& DeVore (1998) the diversity of wood anatomy in 
Calyceraceae (14 species from 5 genera sampled) suggests adaptations to particular ecological conditions, with little phylogenetic information. Characters of fruit morphology are used to delimit Calyceraceae genera. However, Zanotti \& Pozner (in prep.) did not find enough morphological or anatomical evidence to distinguish Boopis from Nastanthus, in agreement with Hellwig (2007), who suggested the synonymy among Nastanthus, Boopis and Moschopsis. Finally, a preliminar molecular phylogeny of the family (Pozner et al. in prep.), suggests that Calycera, Nastanthus and Boopis are not monophyletic.

Because of that poor generic delimitation, some species (particularly those of Nastanthus) are difficult to identify, even with the most comprehensive keys (Pontirolli 1963; Chiapella 1999a), and consequently the identification of herbarium collections is not reliable. In addition, the most recent nomenclatural synopsis of Calyceraceae for southern South America (Zanotti \& Pozner 2008) revealed names that need revision, particularly those combined or synonymyzed under Nastanthus. For these reasons, and toward a complete and comprehensive taxonomic revision of Calyceraceae, we present here the nomenclatural revision of 51 names published, combined or synonymyzed under Nastanthus. We recognized six species, established correct names, new synomyms, lectotypes, updated distribution, and included morphological observations. We do not attempt to present any hypothesis about evolutionary relationships or monophyletic groups, rather just to delimitate species and clear up the nomenclature, which is useful whether Nastanthus later remains as a segregate genus or is merged with another genus, or if a species accepted here is transferred to another genus.

\section{MATERIALS AND METHODS}

Collections of Calyceraceae housed at BAB, CORD, CTES, LIL, MERL, SGO, SI were studied (Holmgren et al. 1990). Type material from BAB, CORD, E, GH, K, LP, P, RNG, SGO, S, SI, W, or their digital images, and original descriptions were also consulted. Drawings of the new species were based on rehydrated herbarium material. Illustrations of Nastanthus patagonicus, N. falklandicus and N. scapigerus were taken from Chiapella (1999a) and reproduced with the editor's authorization.

\section{TAXONOMIC TREATMENT}

Nastanthus Miers, Ann. Mag. Nat. Hist. ser. 3, 6(33): 184. 1860 [Sep 1860].Type species: Nasthanthus agglomeratus Miers (= Nastanthus ventosus (Meyen) Miers).
Perennial, rosulate herbs with napiform, contractile root, and a central, usually unbranched stem (only $N$. falklandicus D.M. Moore might have a rizomatous habit). Leaves more or less fleshy, oblong-oblanceolate to spatulate, glabrous, base attenuate, apex obtuse, blade entire, lobate to pinnatifid, margin entire to dentate. Flowers in head-like pedunculate inflorescences. Peduncles scapiform, fleshy, terete or compressed, smooth or sulcate, solid at anthesis and probably fistulose at fruit maturity, simple or branched, sometimes densely aggregated or coalescent even into a compound terminal inflorescence. Involucre with a patelliform basal tube (absent or very reduced in $N$. falklandicus), with 512 uniseriate lobes, oblong, obtuse, sinuate to trilobate. Receptacle large, fleshy, accrescent during fruit ripening. Palea linear-espatulate, or absent. Flowers numerous. Calyx with suborbicular sepals, with open, valvate or imbricate aestivation, accrescent with the fruit. Corolla funnel-shaped or cyllindrical, usually with a differentiated cup-shaped limb, lobes triangular to oblong, uncinate, with valvate aestivation. Staminal tube inserted in the corolla tube, with 5 oblong nectarial glands, and distally ending in 5 very short filaments. Anthers connate, base sagittate. Style exserted, terete, distally thicker. Stigma globose papillose. Ovary cylindrical, 5-sulcate. Achene prismatic, ridged, corky, crowned by the sepals that surround a terminal apiculum more or less evident. Seed oblong.

According to Miers (1860-1869), Nastanthus forms fertile, short-tubulose flowers and sterile long-tubulose flowers in the same inflorescence. We did not find that flower dimorphism, but a continuous variation in the corolla tube length among flowers in the same inflorescence, being all of them apparently fertile. However, field observations (L. Zavala-Gallo) revealed two types of long-tubulose flowers morphologically alike: one type secondarily exposes pollen on the stigma, while the other type does not, suggesting male sterility. Therefore, Nastanthus does have flower dimorphism, but its relationship with sex expression needs a more detailed anatomical analysis.

Nastanthus includes species endemic to Chile and Argentina (Chiapella 1999b, Zanotti \& Pozner 2008), which grow along the Andes from the $25^{\circ} \mathrm{S}$ towards the south, and all over Patagonia, including Tierra del Fuego and Malvinas (Falkland) Islands. This area corresponds to the phytogeographic Andea-Patagonean Dominion (Altoandine, "del Desierto", Chilean and Patagonean Provinces) and the Subantarctic Dominion (Subantartic and Insular Provinces) (Cabrera \& Willink 1980) (Fig. 1). Although some species of Nastanthus may grow in woody habitats, most of them prefer arid, steppe-like habitats, frequently related to high altitudes, and probably also to streams or ponds due to the presumable hydrocoric dispersal of their fruits (Hellwig 2007). 


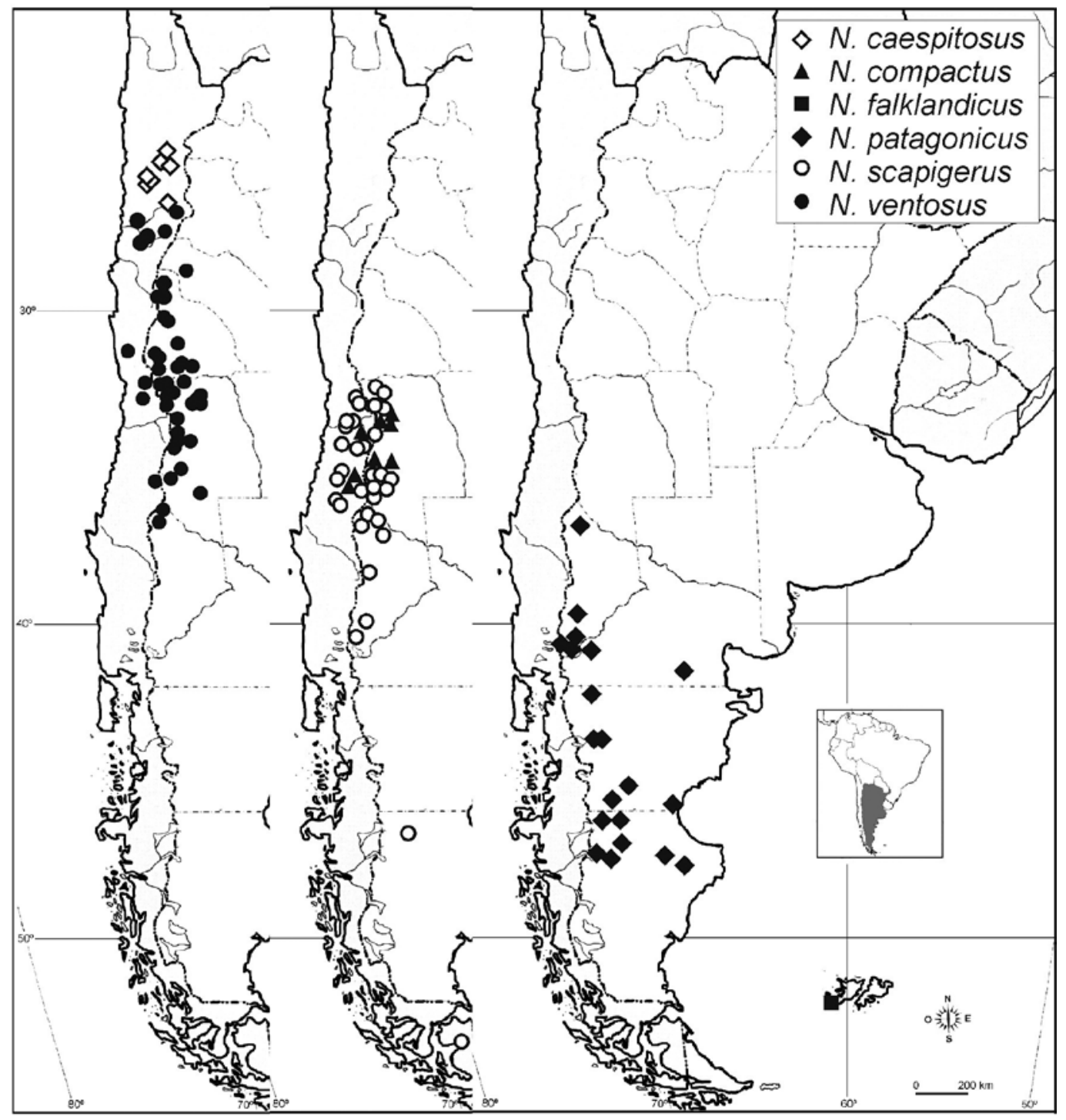

FIGURE 1. Geographical distribution of Nastanthus species.

FIGURA 1. Distribución geográfica de las especies de Nastanthus. 
KeY TO THE SPECIES OF NASTANTHUS

1. Plants not rosulate, leaves densely arranged along the stem, oblong to oblanceolate or subspatulate. Inflorescence terminal, compound, made of pedunculate basal heads, progessively shorter, sessile and coalescent towards the apex. Involucre tube reduced, lobes 3 . . . .

1'. Plants rosulate, leaves spathulate. Inflorescences terminal and lateral, simple, made of scapiform peduncles, distinct, aggregated or partially coalescent, but never forming a compound inflorescence; the terminal inflorescences equal or larger than the lateral ones. Involucre tube developed, lobes 5-12.

2. Corolla lobes short, triangular-dentiform. Stems and inflorescences usually aggregated, caespitose. Receptacle with null or subnull paleae.

3. Corolla cylindrical with a longitudinal, hyaline, thick membrane, accrescent and persistent on the fruit.

2. N. compactus

3'. Corolla funnel-shaped, without a longitudinal membrane, not persistent on the fruit.

4. Corolla about 5.5-7.5 mm long. Nectarial staminal glands of distal position. Achene with uneven ridges. Leaves deeply lobed, almost pinnatisect. 1. N. caespitosus

4'. Corolla about 4-5 mm long. Nectarial staminal glands of median position. Achene with even ridges. Leaves shortly lobed, pinnatifid 6. N. ventosus

2'. Corolla deeply lobed, lobes narrowly triangular to oblong. Stems and inflorescences usually not aggregated or caespitose. Receptacle with linear, spathulate or rectangular paleae.

5. Achenes with narrow laminar ridges, transversely wrinkled. Sepals reduced, non-distinct in the fruit. Central peduncle thick, 1-3 cm diam., bearing a large inflorescence, 1-6 cm diam., surrounded by slender peduncles bearing smaller inflorescences. Corolla tube 2.5-3 mm long, limb 1.6-1.8 $\mathrm{mm}$ long.

4. N. patagonicus

5'. Achenes with expanded laminar ridges, smooth. Sepals distinct in the fruit. Peduncles many, 0.3-1 cm diam., regularly distributed in the plant, all similar in length and thickness, bearing inflorescences of similar size, 0.6-3.5 $\mathrm{cm}$ diam. Corolla tube $4-4.5 \mathrm{~mm}$ long, limb $2.5 \mathrm{~mm}$ long.

5. N. scapigerus

1. Nastanthus caespitosus (Phil.) Reiche, Anales Univ. Chile 106: 1031, 1900. Boopis caespitosa Phil., Fl. Atacam. 26: 200, 1860. TYPE: Chile. "Rio Frio in deserto Atacamensis". II-1854. R. A. Philippi s.n. (lectotype, here designated, SGO-043609, photo SI!; isotypes: SGO-057221, photo SI!, W-0021368, photo SI!, W, photo 31051 by Field Museum of Natural History at SI!). Fig. 2.

Perennial, rosulate herbs about $3.5 \mathrm{~cm}$ tall and $10 \mathrm{~cm}$ in diam., with a central, short stem. Leaves thick, spatulate, $4-5.5 \mathrm{~cm}$ long, base attenuate into a petiole of 2.5-4 x $0.3-1 \mathrm{~cm}$; blade almost pinnatisect, $0.5-1.5 \times 0.3-0.5 \mathrm{~cm}$, uneven lobules linear, obtuse. Peduncles many, cylindrical, frequently forked, crowded, with a distinctive basal foliose bract, $0.8-1.5 \times 0.25-0.4 \mathrm{~cm}$. Involucre with 5 free lobes, rectangular-elliptic, apex obtuse, barely mucronate, $0.6 \mathrm{x}$ $0.2-0.3 \mathrm{~cm}$. Receptacle convex, $0.4-0.8 \mathrm{~cm}$ in diam., slightly accrescent during fruit ripening. Palea fleshy, rectangularlanceolate, apex obtuse, $3 \times 0.8 \mathrm{~mm}$, about 10 per inflorescence. Flowers 25-30 per inflorescence. Calyx with open or imbricated aestivation, sepals widely triangular, obtuse, $0.8 \times 0.4 \mathrm{~mm}$. Corolla infundibuliform, tube $3-5$ $\mathrm{mm}$ long x $0.15 \mathrm{~mm}$ wide at base to $0.5 \mathrm{~mm}$ distally, limb $2.5 \mathrm{~mm}$ long $\times 1$ 1-2.5 mm wide, lobules triangular, 0.3-0.6 x $0.25-0.5 \mathrm{~mm}$, with valvate aestivation. Staminal tube 3-5 mm, inserted on the upper third of the corolla tube, with 5 oblong nectarial glands, $0.5 \times 0.1-0.2 \mathrm{~mm}$, of distal position, and free apical filaments $0.6 \mathrm{~mm}$ long. Anthers 1.4 $\mathrm{mm}$ long. Style exserted, $6 \mathrm{~mm}$ (staminate phase) to 10.5 $12 \mathrm{~mm}$ long (pistillate phase). Ovary cylindrical, 1.25-1.6 x 1-1.2 mm. Achenes prismatic, depressed, 2.5-3 x 2.5-3 $\mathrm{mm}$, asymmetric because of the uneven development of the ridges, ridges 5 , longitudinal, thick, inflated, frequently 1 or 2 very reduced, rarely with wrinkles on the median portion, crowned by an obvious apiculum, 0.4-0.8 mm long, sepals mostly very reduced on the fruit, or enlarged and scarious, mucronate. Seed 1.7 x $0.6 \mathrm{~mm}$.

Distribution. Endemic to Antofagasta and Atacama, in northern Chile (Fig. 1). 
Etymology. The specific epithet refers to the aggregated disposition of inflorescences, occurring in densely caespitose masses.

This species is denoted by the nectarial glands being located just below the free filaments, at the distal end of the staminal tube, by few flowers per inflorescence, and by depressed fruits. Flowers have a green corolla tube and a white limb.

The specimen SGO-043609 is chosen as lectotype since is the only one whose label is clearly correlated. On SGO-057221 the type material was assembled along with other specimens, so that we can not distinguish which label corresponds to each specimen.

\section{SPeCimENS EXAMINED}

CHILE. Región Antofagasta, Prov. Antofagasta, Vega Incahuasi. 14-I-1898. Gerling s.n. (SI); Valles de Río Frío, 3200 m. 15-I-1944. Muñoz-P. 3891 (SGO); Río Frío, 3500 m. I-1926. Werdermann 1028 (LIL, SI). Región de Atacama, Prov. Copiapó, Pastos Largos. I-1885. F. Philippi 1009-6 (SGO).
2. Nastanthus compactus (Phil.) Miers, Ann. Mag. Nat. Hist. ser. 3, 6: 189, 1860. Boopis compacta Phil., Linnaea 28: 709, 1856. Gamocarpha pumila Miers, nomen superfluum, Ann. Mag. Nat. Hist. ser. 3, 6: 282, 1860. TYPE: Chile. "Cordillera de Linares". I-1856. Germain s.n. (holotype SGO-057224, photo SI!; isotype K000009712, photo SI!, W, photo 31050 by Field Museum of Natural History at SI!). Fig. 3.

Boopis diazi Phil., Anales Univ. Chile 21 (2): 396, 1862. Nastanthus diazi (Phil.) Phil. ex Reiche, Anales Univ. Chile 106: 1029, 1900. TYPE: Argentina. "Portillo, lado de Mendoza". 1861-1862. Diaz s.n. (holotype SGO057217, photo SI!; isotype SI-12721!).

Perennial rosulate, glabrous herbs about $3 \mathrm{~cm}$ tall and 10 $\mathrm{cm}$ diam., with a central short stem. Leaves thick, spatulate, $3.5-4.5 \mathrm{~cm}$ long, base attenuate into a petiole of $2-3 \times 0.3 \mathrm{~cm}$; blade entire or pinnatifid, $1-1.5 \times 0.7-1 \mathrm{~cm}$, with triangular lobes. Peduncles crowded, cylindrical, fleshy, 2-3 x 0.5 $\mathrm{cm}$, usually with a sessile, larger, central inflorescence up to $3 \mathrm{~cm}$ in diam. Involucre with 7 widely triangular lobes,

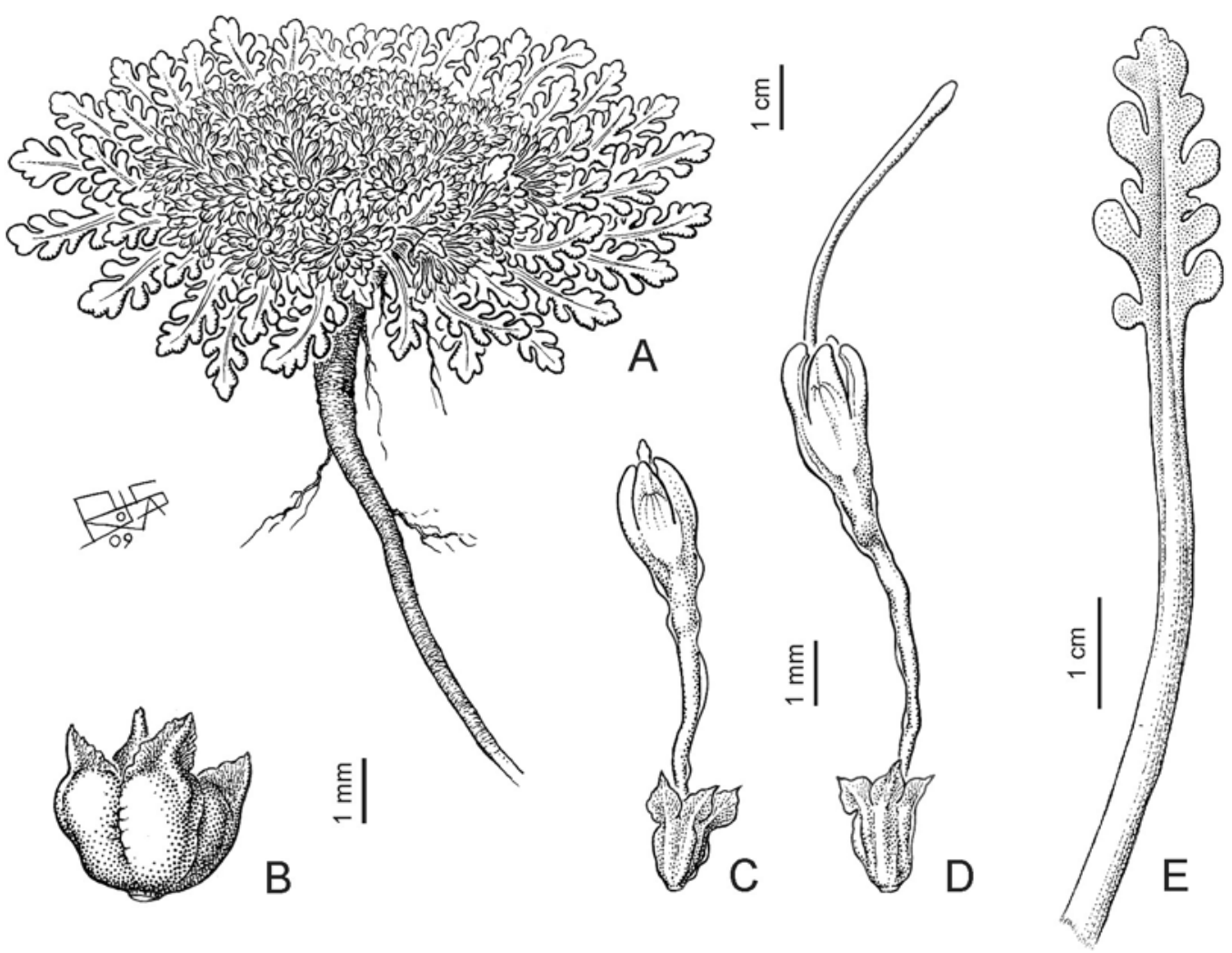

Figure 2. Nastanthus caespitosus. A. Habit. B. Fruit. C. Flower at the staminate phase. D. Flower at the pistillate phase. E. Leaf. Drawn from C. Muñoz-P. 3891 (SGO).

Figura 2. Nastanthus caespitosus. A. Hábito. B. Fruto. C. Flor en fase estaminada. D. Flor en fase pistilada. E. Hoja. Dibujado de C. Muñoz-P. 3891 (SGO). 


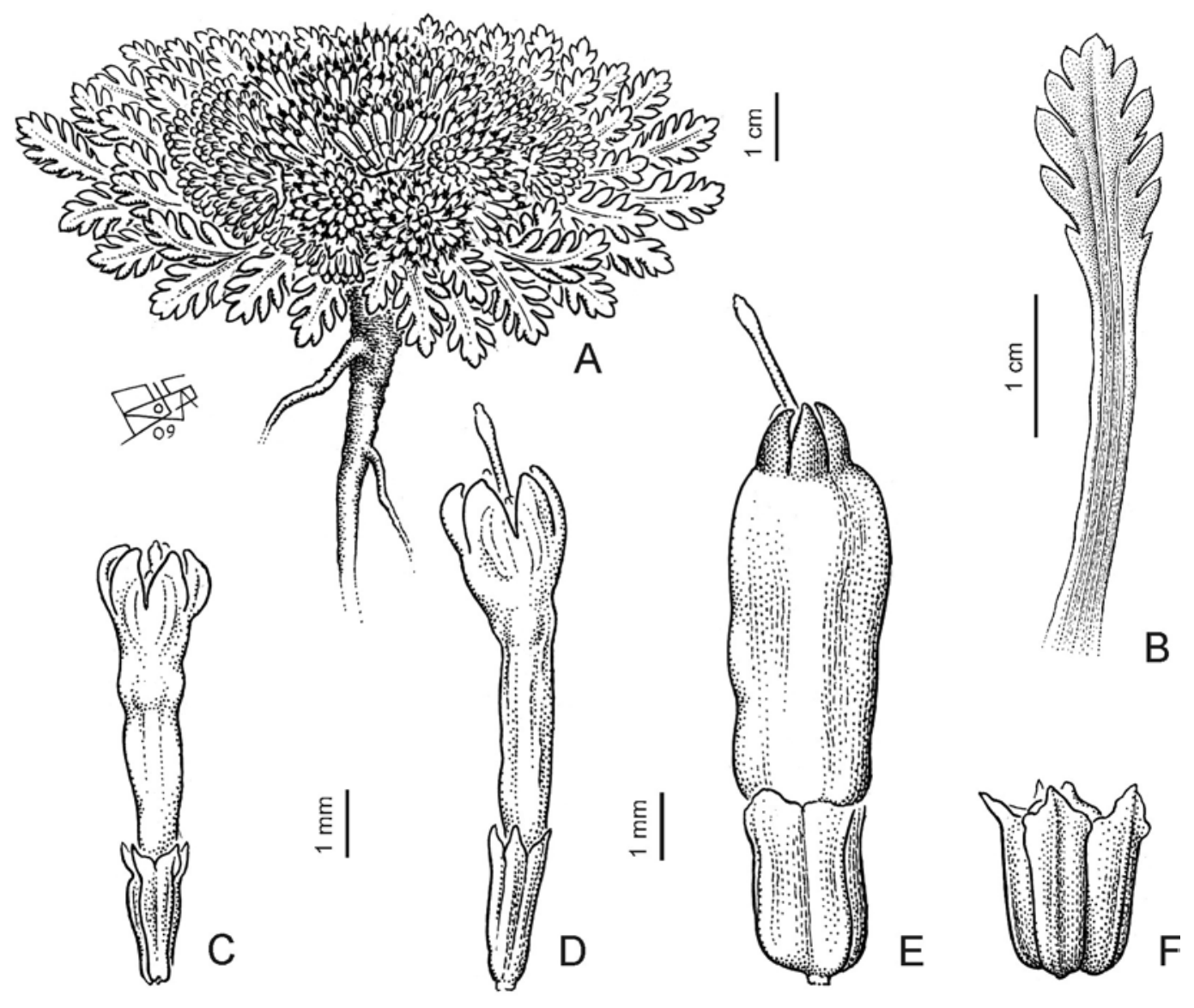

FIgURE 3. Nastanthus compactus. A. Habit. B. Leaf. C. Flower at the staminate phase. D. Flower at the pistillate phase. E. Fruit with persistent, accrescent corolla. F. Fruit (corolla removed). Drawn from J. Solervicens s.n. (SGO-130759).

Figura 3. Nastanthus compactus. A. Hábito. B. Hoja. C. Flor en fase estaminada. D. Flor en fase pistilada. E. Fruto con corola persistente, acrescente. F. Fruto (corola removida). Dibujado de J. Solervicens s.n. (SGO-130759).

$0.3 \mathrm{~mm}$ long x $0.4 \mathrm{~mm}$ wide each. Receptacle convex, $0.5-3 \mathrm{~cm}$ in diam., accrescent during fruit ripening. Palea absent. Flowers white, 100-115 per inflorescence, up to some hundred in the central inflorescence. Calyx with open aestivation, sepals suborbicular, obtuse, $0.5 \times 0.3$ $\mathrm{mm}$. Corolla cylindrical, tube $3 \times 1 \mathrm{~mm}$, limb slightly campanulate, $2-2.5 \mathrm{~mm}$ long $\times 1.4 \mathrm{~mm}$ wide, lobes triangular, uncinate, $0.7-1 \times 0.5-0.8 \mathrm{~mm}$, aestivation valvate. Staminal tube 3-4 mm long, inserted in the upper third of the corolla tube, with 5 oblong nectarial glands $0.5 \times 0.2 \mathrm{~mm}$ of median position, apical free filaments of 0.3-0.5 mm. Anthers 1.1 $\mathrm{mm}$ long. Style exserted, $4.5 \mathrm{~mm}$ (staminate phase) to 7 $\mathrm{mm}$ (pistillate phase). Ovary cylindrical 1.8-2.2 x 0.6-0.8 $\mathrm{mm}$. Achenes white, prismatic, 2.2-2.6 x 1-1.7 mm, with 5 narrow, longitudinal, flat ridges crowned by the sepals, 0.5-0.7 $\times 0.35-0.8 \mathrm{~mm}$, surrounding a central cupuliform apiculum, 0.2-0.4 mm long; corolla accrescent on the fruit, green-reddish, tube 5-5.5 x 2-2.5 mm, $\operatorname{limb} 1.3 \times 1.2-1.4$ $\mathrm{mm}$. Seed 1.6-1.8 x $0.6 \mathrm{~mm}$.

Distribution. Andes of Chile and Argentina, between $32^{\circ}-$ $36^{\circ} \mathrm{S}$, since $3000 \mathrm{~m}$ (Fig. 1).

Etymology. The specific epithet refers to the inflorescences that grow in a confluent mass, strongly aggregated.

This is the only species of Nastanthus with an accrescent corolla persistent on the fruit (in the remaining species the corolla may persist, but it is non-accrescent and withered) and without inflorescence paleas. The corolla is tubulose and white, but during fruit ripening the tube turns green towards the apex, and the limb turns reddish, while most of the corolla tube remains white, and swells by the development of a spongy tissue, similar to that of the fruit ridges. 
The analysis of original material reveals that Boopis diazi is based on an specimen that should have been assigned to $N$. compactus. This specimen possesses all distinct attributes of the species (spatulate-pinnatifid blades, short peduncles, flowers with reddish calyx teeth, long and cylindrical corolla tube, and an accrescent corolla persistent on the fruit).

Gamocarpha pumila is a nomenclatural synonym of Boopis compacta because the type material of the former housed at $\mathrm{K}$ is an isotype of the latter. This conclusion is based on the finding that both types are fragments of a single plant. Moreover, labels on both sheets specify the same collector and date (Ph. Germain, 1856-1857), but differ in location. The holotype in SGO indicates "Cordillera de Linares" and the type in K "Cordiliéres de Maule (sede orient)"; nevertheless, from 1826 to 1873 , Linares was part of the administrative subdivision of Maule province.

SPECIMENS EXAMined

ARGENTINA. Prov. Mendoza, Depto. San Rafael, Camino a Mina Volcán Overo, 3000-3200 m. III-1945. Christoffel s.n. (LIL); Cajón del arroyo Infiernillo, afl. río Grande. 10-
II-1946. Rossi s.n. (LIL). Depto. Tunuyán, Valle del Alto Tunuyán. 27-XII-1933. Ruiz Leal s.n. (LIL); Rincones del Cerro Morado, 3700 m. 21-III-1935. Ruiz Leal 3177 (MERL). Depto. Luján de Cuyo, Luján de Cuyo, Placetas Bayas (Loma Blanca), 3000-3300 m. 5-I-1937. Semper s.n. (MERL). CHILE. Región Metropolitana, Prov. Cordillera, Valle Nevado última pista, trayecto entre Alto Tres Puntas hasta Piedra Numerada, camino a El Plomo, 3000-3500 m. I-1993. Solervicens s.n. (SGO). Región del Maule, Prov. Curicó, Andes de Curicó, Santa Elena. II-1902. Rivera s.n. (SI). Prov. Talca, Laguna de Aguas Calientes, Andes. II1879. F. Philippi 2049 (SGO).

3. Nastanthus falklandicus D.M. Moore, Bot. Not. 120: 18, 1967. TYPE: Falkland Islands (Islas Malvinas). "West Falkland (Gran Malvina): Port Stephens, Ten Shilling Bay Peninsula, west coast ca. 3 miles SE Stephens Peak, in gravel and sand between loose rock slabs near cliff top, also on bare cliff ledges", 90 m. 28I-1964, Moore 707 (holotype K-000634091, photo SI!; isotypes: BAB!, GH-00283130, photo SI!, RNG, photo SI!, S09-36193, photo SI!). Fig. 4.

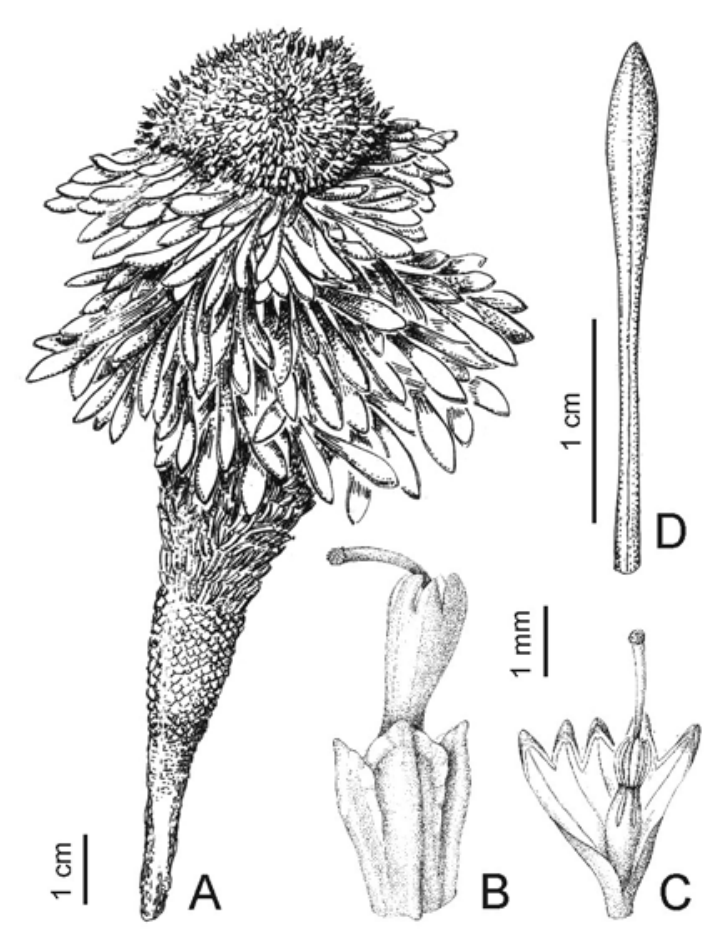

Figure 4. Nastanthus falklandicus. A. Habit. B. Flower at the pistillate phase. C. Dissected corolla showing the staminal tube (flower at pistillate phase). D. Leaf. (Taken from Chiapella 1999a).

Figura 4. Nastanthus falklandicus. A. Hábito. B. Flor en fase pistilada. C. Corola diseccionada para mostrar el tubo estaminal (flor en fase pistilada). D. Hoja. (Tomado de Chiapella 1999a). 
Perennial, glabrous herb; stem about 2-7 $\mathrm{cm}$ tall and 0.5-1.8 $\mathrm{cm}$ in diam., fleshy, solid, wider towards the apex, ending into a compound inflorescence, narrowing to the base into a more or less horizontal structure (rhizome?). Leaves densely imbricate, $1.2-4 \mathrm{~cm}$ long x $0.2-0.4 \mathrm{~cm}$ wide, narrowly oblong to oblanceolate or subspatulate, base attenuate into a petiole; blade entire, fleshier than the petiole, with a median longitudinal groove, apex acute to rounded. Inflorescence terminal, compound, made of basal pedunculate heads that becomes sessile and coalescent towards the apex of the stem; basal peduncles usually simple, $2 \mathrm{~cm}$ long, one-headed, with a basal foliar bract, which becomes closer to the involucre in the upper heads. Involucre with 3 narrowly triangular bracts, $0.2-0.3$ x 0.3-0.4 cm, basally connate. Receptacle $0.4-0.8 \mathrm{~cm}$ in diam. Palea 6-10 per head, narrowly elliptic to oblanceolate, $0.05 \times 0.15-0.3 \mathrm{~cm}$. Flowers white. Sepals obtuse to rounded, $0.5 \times 0.5 \mathrm{~mm}$. Corolla cylindric, $3 \mathrm{~mm}$ long, tube $2 \mathrm{~mm}$ long, lobes acute triangular, cucullate, $0.8 \mathrm{~mm}$ long. Staminal tube inserted in the basal half of the corolla tube, with 5 nectarial glands, and free, distal, short filaments. Anthers $0.6 \mathrm{~mm}$ long. Style exserted, about $1 \mathrm{~mm}$ long. Immature achenes prismatic, $2.5 \mathrm{~mm}$ long, with 5 longitudinal ridges crowned by the sepals. Mature achenes unknown.

Distribution. It is endemic to the Malvinas (Falkland) Islands, apparently restricted to the southwestern coast of the Gran Malvina/West Falkland Island (Moore 1967; Fig. 1).

Etymology. The specific epithet refers to the geographic site where this species is circumscripted (Malvinas (Falkland) Islands).

Species only known by the type collection and one paratype collected in 1839, Robinson s.n. (K) (Moore 1967). As we could not study the type material, the description was based on the original publication of Moore (1967). According to this author, $N$. falklandicus is protogynous, a very improbable feature considering the mechanism of secondary pollen presentation typical of Calyceraceae (Erbar \& Leins 1995).

This species is distinguishable by its habit, with narrowly oblong to oblanceolate or subspatulate leaves densely arranged along the stem, and compound inflorescences. Flowers are white and smell strongly of nectar.

4. Nastanthus patagonicus Speg., Anales Mus. Nac. Buenos Aires 7: 307, 1902. TYPE: Argentina. "Rarissime in aridissimis saxosis prope Teka-choique". XII-1899. N. Illín s.n. (holotype LP-11033!, photo SI!). Fig. 5.

Acarpha laciniata Stapf, Bot. Mag. 155: sub t. 9272, 1929 [1932]. TYPE: Argentina. Croit sur les ou entre les cailloux sur les rives du Limay et du Chubut. Patagonie. 1865. Claraz 93 (holotype K-000009720, photo SI!).
Perennial rosulate herbs about $2-25 \mathrm{~cm}$ tall and $6-20 \mathrm{~cm}$ in diam., with a short stem. Leaves thick, spatulate, 2-7 $\mathrm{cm}$ long, base attenuate into a petiole of 1.3-4 x 0.15-0.5 $\mathrm{cm}$; blade $0.8-3 \times 0.8-3 \mathrm{~cm}$, lobed, margin dentate, lobes obtuse to triangular, mucronate. Peduncles cylindrical, 2-20 x 0.1-0.5 cm, with a central, larger peduncle of $15 \times 3 \mathrm{~cm}$ in old specimens. Involucre with 5-7 lobes, 0.5-1 x 0.35$0.8 \mathrm{~cm}$, variable in shape: triangular mucronate at apex; triangular, minutely dentate, with apex and teeth mucronate; or spatulate lobate with apex and lobules mucronate. Receptacle convex, 1-6 cm in diam., accrescent during fruit ripening. Palea thick, spatulate to rectangular, apex obtuse mucronate, $0.35 \times 0.1 \mathrm{~cm}$ in receptacles with flowers to 1 $\mathrm{x} 0.7 \mathrm{~cm}$ in receptacles with fruits. Flowers whitish-green, 20-500 per inflorescence, up to 1,000 in the central, larger head. Calyx with open or imbricate aestivation; sepals small, suborbicular, emarginate, translucent, 0.3-0.4 x 0.5-0.7 mm. Corolla infundibuliform, tube $2.5-3 \mathrm{~mm}$ long $\times$ 0.8-1.2 mm wide, limb 1.6-1.8 x $0.9 \mathrm{~mm}$, lobes triangular, uncinate, 1.4$1.8 \times 0.8-0.9 \mathrm{~mm}$, with valvate aestivation. Staminal tube 3 $\mathrm{mm}$, inserted on the upper third of the corolla tube, with 5 oblong, indistinct, nectarial glands, $0.6 \times 0.2 \mathrm{~mm}$, of median position, and apical free filaments $0.2-0.4 \mathrm{~mm}$. Anthers 1 $\mathrm{mm}$ long. Style exserted, $5 \mathrm{~mm}$ (staminate phase) to $6 \mathrm{~mm}$ long (pistillate phase). Ovary cylindrical, 1.4-2 x 0.8-1 mm. Achenes prismatic, wrinkled, 2.4-2.7 x 1-1.6 mm, with 5 longitudinal, thin, narrow, laminar ridges, crowned by an apiculum 0.25-0.35 mm long, with reduced or accrescent lanceolate sepals $(1 \times 1 \mathrm{~mm})$. Seed $2 \times 0.7 \mathrm{~mm}$.

Distribution. Endemic to southern Argentina, from north Neuquén to Santa Cruz (Fig. 1), occurring both in the steppe and the Andean forests.

Etymology. The specific epithet refers to the geographic region where this species exclusively grows.

This species is distinguishable by the largest inflorescences within the genus, with a central head of $1-6 \mathrm{~cm}$ diam., which may sustain ca. 1,000 flowers; paleas are also large. Flowers are greenish-white with long corolla limbs.

According to Chiapella (1999a), young individuals of $N$. patagonicus can be misidentified as $N$. scapigerus due to the overall similarity of the leaves, flower colour, inflorescences and habit. The absence of a central, larger peduncle and inflorescences of similar size in young individuals of $N$. patagonicus increase the similarity between both species. However, both entities can be still discerned by the morphology of fruit ridges and sepals, and flower size.

\section{SPECIMENS EXAMINED}

ARGENTINA. Prov. Neuquén. Depto. Minas, Cordillera del Viento, cruzada de Triaco Malal al Cajón de Butaló, portezuelo, $36^{\circ} 58^{\prime} \mathrm{S}, 70^{\circ} 31^{\prime} \mathrm{W}, 2300 \mathrm{~m}$. 3-II-1964. Boelcke et 


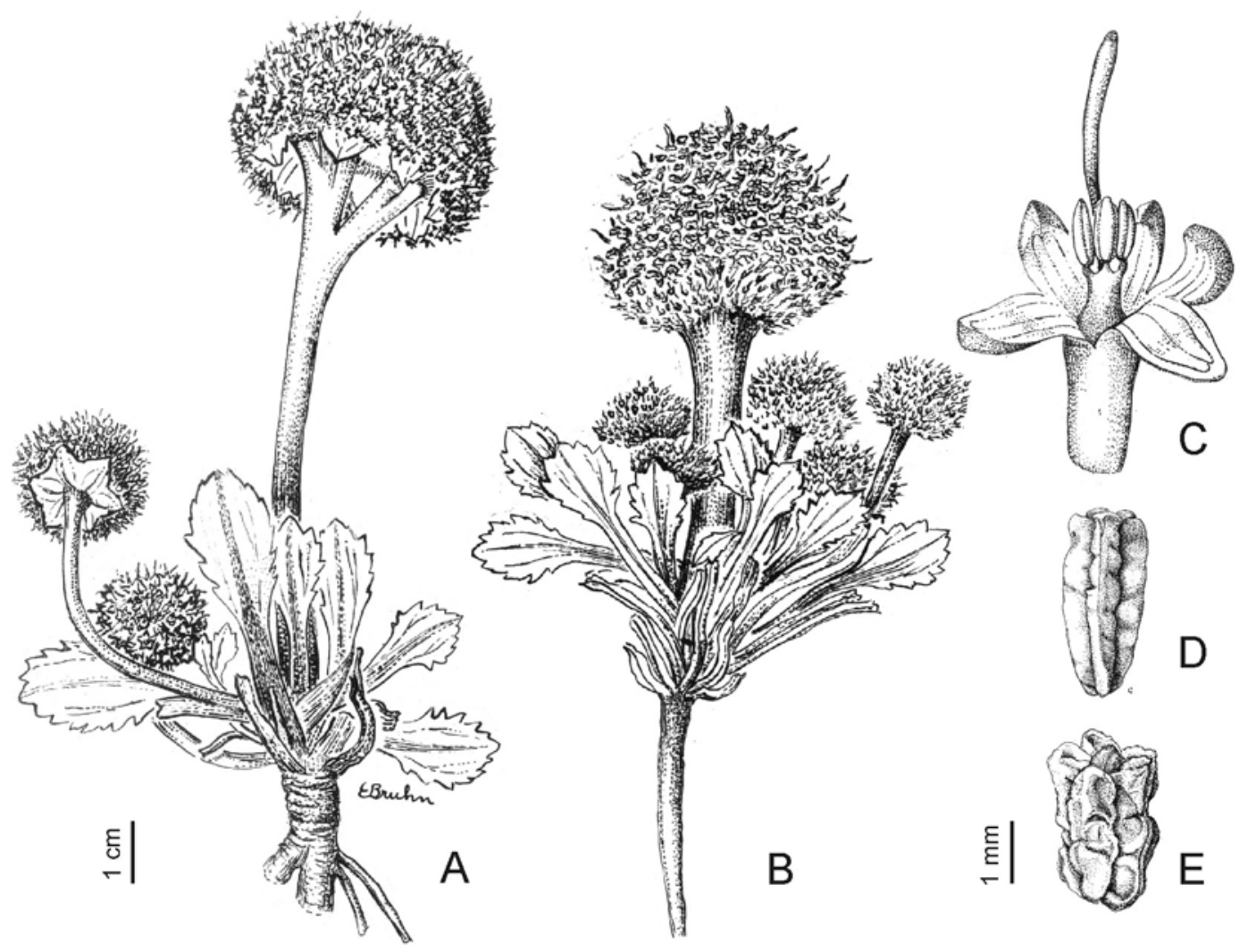

Figure 5. Nastanthus patagonicus. A-B. Habit. C. Flower (ovary removed). D-E. Fruit variation. (Taken from Chiapella, 1999a: A, C and D, sub. N. patagonicus; B and E, sub. N. scapigerus).

Figura 5. Nastanthus patagonicus. A-B. Hábito. C. Flor (ovario removido). D-E Variación del fruto. (Tomado de Chiapella, 1999a: A, C y D, sub. N. patagonicus; B y E, sub. N. scapigerus).

al. 11624a (SI). Depto. Collón-Curá, \pm 10 km de Rinconada. 18-XII-1985. Correa et al. 9387 (BAB). Depto. Lácar, C ${ }^{\circ}$ Chapelco, faldeo NW, 2000 m. 26-I-1966. Eskuche 603-7 (CTES); San Martín de los Andes, cerro Chapelco, $1900 \mathrm{~m}$. 26-I-1982. Rossow 1502 (BAB); $\mathrm{C}^{\circ}$ Chapelco, al S de San Martín de los Andes, 2000 m. 8-III-1964. Schajovskoy s.n. (SI); Cerro Chapelco, del refugio Greef hacia arriba. 3-I1983. Villamil et al. 2790 (SI). Depto. Aluminé, Espinazo del Zorro, 1500 m. 6-XII-1964. Schajovskoy 55/IV (SI). Prov. Río Negro. Depto. Pilcaniyeu, Ruta 40 cerca cruce Ruta 23. 10-X-1981. Cabrera et al. 33027 (SI). Depto. Bariloche, Nireco, 1600 m. 7-XII-1941. Neumeyer 545 (SI). Depto. 9 de Julio, Ruta Prov. 60, a 65,5 km SW del Puesto Policial, cerca del $\mathrm{C}^{\circ}$ Corona (e/ $\mathrm{C}^{\circ}$ Corona Grande y Chico), $41^{\circ} 23^{\prime} 41^{\prime \prime} \mathrm{S}$, 66 57'33"W, 1425 m. 3-XI-2006. Zanotti \& Ávila 26 (SI). Prov. Chubut. Depto. Senguerr, Ruta 22, 2 km N Río Mayo, 4539'S, 70¹5'W. 7-XII-1976. Arroyo et al. 353 (SI). Depto.

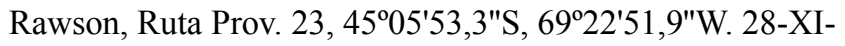
2002. Bonifacino \& Donato 734 (SI). Depto. Languiñeo, $C^{\circ}$ Quichaura, Estancia "Quichaura", 1500 m. 19-XII-1946. Soriano 2297 (SI); 41 km E of Tecka. Estancia Quichaura, on Route Prov. 62, to the right of the road going W-E, 900 m. 6-XII-1984. Stuessy et al. 6871 (SI). Depto. Escalante, Comodoro Rivadavia. Wilensky s.n. (SI). Depto. Cushaman, Ruta Pcial. 13, a 17,7 km S del límite Chubut-Río Negro, Sierra de Calcatapul, 42 $04^{\prime} 25^{\prime \prime S}, 6^{\circ} 30^{\prime} 54^{\prime \prime W}, 1219$ m. 5XI-2006. Zanotti \& Ávila 57 (SI). Prov. Santa Cruz. Depto. Río Chico, $22 \mathrm{~km}$ al $\mathrm{W}$ de Bajo Caracoles hacia Lago Posadas, planicie del río Blanco, $47^{\circ} 34^{\prime} \mathrm{S}, 71^{\circ} 12^{\prime} \mathrm{W}$. 26-I1967. Boelcke et al. 12815 (SI). Depto. Deseado, Ruta Prov.

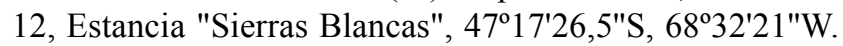
2-XII-2002. Bonifacino \& Donato 769 (SI); Monumento Natural "Bosques Petrificados", cercanías Aguada del Sauce. 20-XII-1994. Montenegro 37 (CTES). Depto. Lago Buenos Aires, Lago Ghio, 400 m. 28-I-1930. Donat s.n. (LIL); Ruta Nac. 40; 8,4 km al S de Estancia "Telken", 46 $52^{\prime} 01 " \mathrm{~S}, 70^{\circ} 43^{\prime} 58^{\prime \prime} \mathrm{W}, 619$ m. 9-I-2008. Paiaro s.n. (SI); Estancia "El Cerrito", Ruta Prov. 45, 7,7 km SE empalme Ruta Prov. 72,6,3 km NW Estancia "Bahía", 46²15'46"S, $71^{\circ} 22^{\prime} 39^{\prime \prime}$, 634 m. 10-I-2008. Paiaro s.n. (SI); Ruta Nac. 40, $59 \mathrm{~km} \mathrm{~S}$ Perito Moreno. 8-XII-1986. Sánchez 448 (BAB); Ruta Prov. 39, a 84,9 km E Bajo Caracoles, 17,8

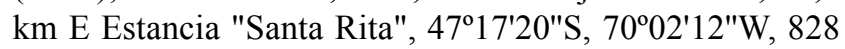
m. 21-I-2007. Zanotti 141 (SI). 
5. Nastanthus scapigerus (J. Remy) Miers, Ann. Mag. Nat. Hist. ser. 3, 6: 188, 1860. Boopis scapigera J. Remy in Gay, Hist. Chile, Bot. 3(3): 250, 1848. TYPE: Chile. "Provincias del Sud". Gay s.n. (lectotype P, here designated, photo 37100 by Field Museum of Natural History at SI!). Fig. 6.

Boopis spathulata Phil., Linnaea 28: 708, 1856. Nastanthus spathulatus (Phil.) Miers, Ann. Mag. Nat. Hist. ser. 3, 6: 189, 1860. TYPE: Chile. "Cordillera de Linares". I1856. R. A. Philippi s.n. (lectotype, here designated, SI12723!; isotype W, photo 31053 by Field Museum of Natural History at SI!).

Nastanthus laciniatus Miers, Ann. Mag. Nat. Hist. ser. 3, 6: 187, 1860. Boopis laciniata (Miers) Ball, J. Linn. Soc., Bot. 21: 220, 1884 [1886 publ. 1884], Nastanthus agglomeratus Miers var. laciniatus (Miers) Reiche, Anales Univ. Chile 106: 1030, 1900. Boopis (Nastanthus) agglomerata (Miers) Hauman var. laciniata (Miers) Hauman, An. Soc. Cient. Arg. 85: 312, 1918. TYPE: Chile. "Cordillera Chile". Cuming 326 (lectotype, here designated, K-000009721, photo SI!; isotypes BM- 000947741, photo SI!, E-00259116, photo SI!, E00259118, photo SI!).

Boopis araucana Phil., Anal. Univ. Chile 41: 736, 1872. Nastanthus araucanus (Phil.) Reiche, Anales Univ. Chile 106: 1033, 1900. TYPE: Chile. "San Lorenzo a orillas del río Duqueco". Volkmann s.n. (lectotype, here designated, SGO-057225, photo SI!; isotypes: SGO043594, photo SI!, K-000009716, photo SI!).

Boopis bellidifolia Phil., Anales Univ. Chile 41: 736, 1872. Nastanthus bellidifolius (Phil.) Reiche, Bot. Jahrb. Syst. 29: 114, 1900. Nastanthus spathulatus (Phil.) Miers var. bellidifolius (Phil.) Pontiroli, Revista Mus. La Plata, Secc. Bot. 9(41): 238, 1963. TYPE: Chile. "Valle de las Damas, cordillera del Tinguiririca”. I-1872. R.A. Philippi s.n. (holotype SGO-057215, photo SI!; isotype SI-12717!).

Boopis reichei Phil., Anales Univ. Chile 85: 815, 1894. TYPE: Chile. "In Andibus editioribus provinciae Santiago, v. gr. in Valle largo". II-1892. Reiche s.n. (holotype SGO-057216, photo SI!; isotype SI-12724!).

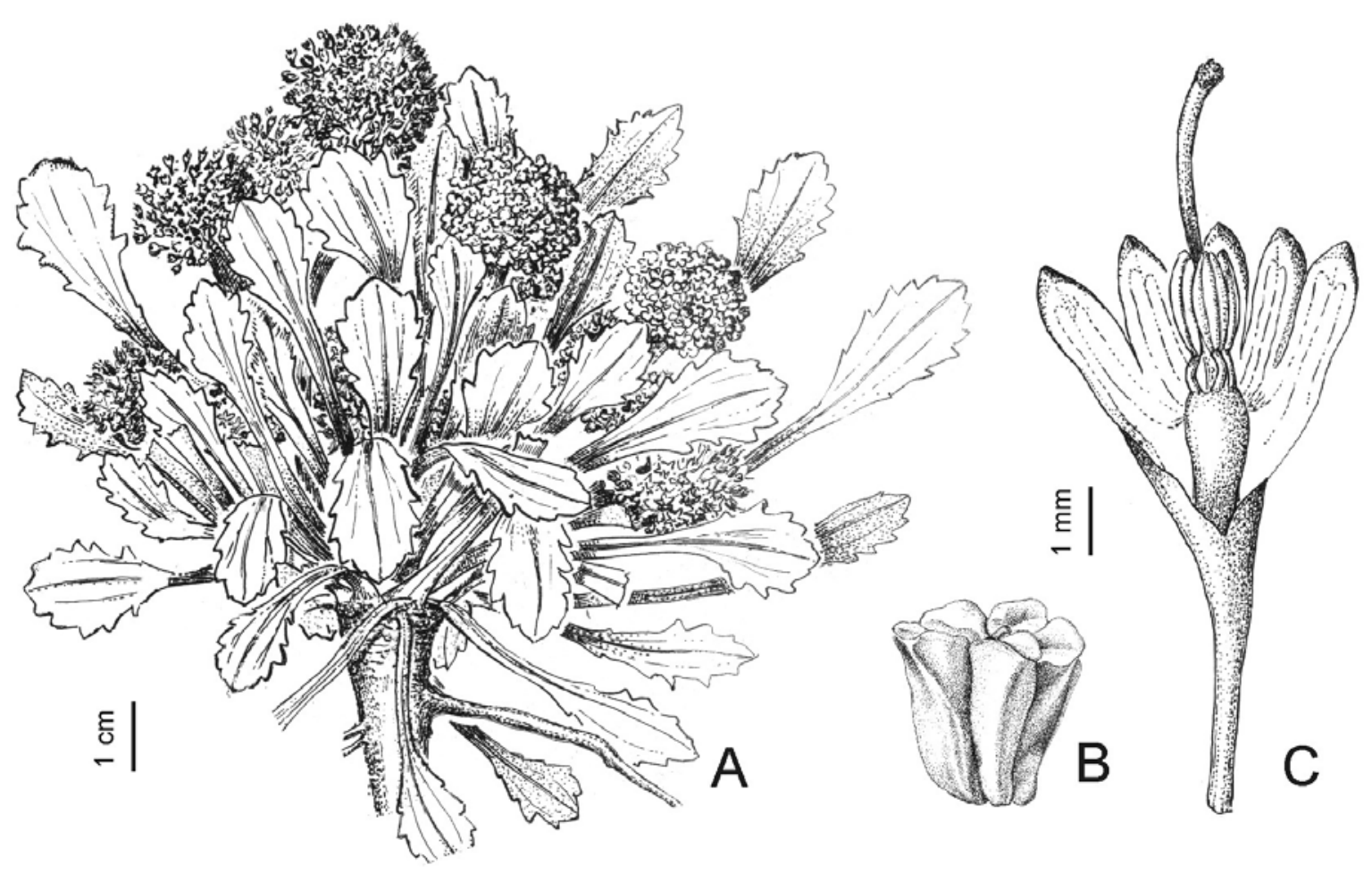

Figure 6. Nastanthus scapigerus. A. Habit. B. Fruit. C. Corolla partially showing the staminal tube (ovary removed). (Taken from Chiapella 1999a, sub. N. spathulatus).

Figura 6. Nastanthus scapigerus. A. Hábito. B. Fruto. C. Corola que muestra parcialmente el tubo estaminal (ovario removido). (Tomado de Chiapella 1999a, sub. N. spathulatus). 
Boopis dubia Phil., Anales Univ. Chile 85: 815, 1894. TYPE: Chile. "Cordillera de Peuco in provincia O'Higgins (Cádiz)", without collector (holotype SGO057218, photo SI!).

Boopis miersii Phil., Anales Univ. Chile 85: 817, 1894. TYPE: Chile. "Andes de Linares en las provincias de Curicó, Colchagua, Santiago". XI-1858. Germain s.n. (holotype SGO-057238!).

Nastanthus chubutensis Speg., Anales Mus. Nac. Buenos Aires 7: 306, 1902. Nastanthus bellidifolius (Phil.) Reiche var. chubutensis (Speg.) Hicken, Reun. Nac. Soc. Arg. Cienc. Nat. 1: 250, 1919. TYPE: Argentina. "In rupestribus aridis prope Carren-leofú". I-1901. C. Spegazzini s.n. (holotype LP-11034!, photo SI!).

Perennial, rosulate, glabrous herbs, about $3-10 \mathrm{~cm}$ tall and $10-$ $25 \mathrm{~cm}$ in diam., with a central short stem. Leaves spatulate, thick, 5-10 cm long, apex obtuse, base attenuate into a petiole of 2-8 x 0.2-0.3 cm; blade 1-4 x 0.5-2.5 cm, entire with margin entire to dentate, or irregularly pinnatifid, and lobes obtuse to triangular, minutely mucronate. Peduncles many, densely crowded, terete, fleshy, sometimes branched, $2-12 \times 0.3-1 \mathrm{~cm}$, occasionally a central larger peduncle, 6 x $1 \mathrm{~cm}$. Involucre with 5-7 widely triangular, mucronate lobes, $0.55 \times 0.5 \mathrm{~cm}$ (sometimes spatulate, $0.75 \times 0.35$ $\mathrm{cm}$ ), margin entire or with few teeth. Receptacle convex, $0.6-3.5 \mathrm{~cm}$ in diam., accrescent during fruit ripening. Palea sparse, green, fleshy, linear spatulate, apically mucronate, $0.5 \mathrm{~mm}$ long. Flowers green, usually $45-80$ per head up to 150 in the larger central inflorescences. Calyx with aestivation imbricated; sepals suborbicular, apex usually emarginate, margin minutely toothed, $1-1.4 \times 1-1.4 \mathrm{~mm}$. Corolla infundibuliform, tube 4-4.5 mm long x 0.2-0.4 mm in diam. at base to $0.8 \mathrm{~mm}$ distally, limb $2.5 \mathrm{~mm}$ long. $\mathrm{x} 0.5$ $1 \mathrm{~mm}$ in diam., completely cleft, lobes triangular, uncinate, $2.2 \times 0.8 \mathrm{~mm}$, with valvate aestivation. Staminal tube 4-5 $\mathrm{mm}$, inserted in the upper third of the corolla tube; with 5 oblong nectarial glands, $0.8 \times 0.2 \mathrm{~mm}$, of median position, and apical free filaments $0.5 \mathrm{~mm}$ long. Anthers $1.4 \mathrm{~mm}$ long. Style exserted, $6 \mathrm{~mm}$ (staminal phase) to $10 \mathrm{~mm}$ long (pistillate phase). Ovary cylindrical 2.2-3 x $1.4-2.2 \mathrm{~mm}$. Achenes prismatic 3-5.5 x 2.5-4 mm, with 5 longitudinal, smooth, well developed, expanded ridges crowned by the sepals (1-2.15 x 1.2-2.8 mm), apiculum $0.8 \mathrm{~mm}$ long. Seed $2-3.5 \times 0.75 \mathrm{~mm}$.

Distribution. Andes of Chile and Argentina, mostly between $32^{\circ}-40^{\circ} \mathrm{S}$ and isolated records occurring in Chubut and Santa Cruz provinces (Argentina) and Tierra del Fuego island (Inútil Bay, Chile; Fig. 1).

ETymology. The specific epithet appears to refer to the scapiform inflorescence peduncle.
There are three specimens of the original material from Claudio Gay collection with labels of Herb. Mus. Paris; one of them is housed at $\mathrm{P}$ and the other two are conserved at $\mathrm{K}$. The $\mathrm{P}$ specimen is selected as lectotype since vegetative and reproductive structures are well preserved and it better matches Rémy's description. One of the specimens at $\mathrm{K}$ also matches the original description but it consists in a single and fragmentary plant. The other sheet at $\mathrm{K}$ includes poorly preserved fragments of a plant that do not match with Rémy protologue of Boopis scapigera. This material was originally identified as "Boopis scapigera Remy", it shows the pencil inscription "non" on the name, and, at the margin of the sheet, an incomplete inscription where "Nastan..." can be read. These inscriptions appear in all specimens revised by Miers for his Contributions to Botany (1860-1869). This specimen from $\mathrm{K}$ is part of the material used by Miers to typify Nastanthus pinnatifidus (= Nastanthus ventosus); its references agree with the protologue and it has been relocated on the same sheet with the syntype Cuming 325 .

The name Nastanthus spathulatus is one of the better known among Chilean and Argentinean botanists and it is based on Boopis spathulata. Nevertheless, all characters of the B. spathulata types found at SI and W clearly match the type material of Boopis scapigera; the only difference is that $B$. spathulata holotype is a specimen bearing flowers and broad blades, whereas the B. scapigera lectotype (P) bears fruits. Miers (1860-1869) noted the similarity between both species but he drew no conclusion because he had not seen the Philippi holotype. However, these similarities are evident in the illustration of $N$. scapigerus in Miers (18601869). The specimen at SI is chosen as lectotype since is the best conserved and has the Philippi's label.

Miers (1860-1869) established the new species Nastanthus laciniatus based on three specimens from different collectors. Later, Reiche (1900) treated this taxon as a variety of $N$. agglomeratus. The analyses of their syntypes revealed that they correspond to $N$. scapigerus, because of their corolla limb completely cleft. Considering the three syntypes available in K, Cuming 326, from "Cordillera de Chile", is the best preserved, retaining the plant form with many inflorescences and achenes, and perfectly matches Miers' description. The remainder syntypes, Gillies s.n. from "Los Palomares" and Bridges s.n. from "Ojos de Agua", conserve more vegetative structures (leaves and roots), but fewer reproductive ones, that are required to identify the species and were especially used by Miers.

Some of the synonymies here listed were cited in synonymy before: Boopis dubia and Boopis reichei under Nastanthus spathulatus; and Boopis miersii under Nastanthus scapigerus (Reiche 1900, Zanotti \& Pozner 2008). All of them represent morphological forms related with distinct environmental pressures that exist in the Andean-Patagonian distribution of the species, including longitudinal, latitudinal and altitudinal ranges. 
Boopis araucana, only known from type material, is a specimen with longer, more branched and leafy peduncles than the typical condition in $N$. scapigerus, but an exhaustive study on inflorescences form, flowers and leaves, show that both taxa are conspecific. The specimen SGO-057225 is chosen as lectotype since it possesses more reproductive material than SGO-043594.

Due to the existence of many forms within $N$. scapigerus and the lack of characters to distinguish between both taxa we consider Boopis bellidifolia as a synonym of $N$. scapigerus.

Nastanthus chubutensis was created based on two specimens from the Andean limit of Chubut province of Argentina. Its characters match the Boopis scapigera description of Remy and also its general aspect resembles the lectotype of $B$. scapigera since all possess fruits. Probably, these similarities were noted before by Hicken (1919), who considered Nastanthus chubutensis as a variety of $N$. bellidifolius.

The comparison between $N$. scapigerus and related taxa, treated here as synonyms, shows that vegetative morphological characters are scarcely variable, and the reproductive ones (floral characters) remain constant (Table I).

The illustration published by Chiapella (1999a: 514, Fig. 397) of $N$. scapigerus corresponds to N. patagonicus.

\section{SPECIMENS EXAMINED}

ARGENTINA. Prov. Mendoza. Depto. Las Heras, Cuevas, Quebrada de Matienzo. 11-II-1982. Andrada et al. s.n. (SI). Quebrada de Matienzo, 3200-3800 m. 26II-1962. Capitanelli s.n. (MERL). Las Cuevas, Refugio Militar "Gral. Lamadrid". 10-I-1963. Boelcke et al. 9730 (SI). Puente del Inca. 22-I-1914. Sanzin 361 (SI). Depto. Malargüe, Alto Valle de El Sosneado, 2700 m. 19II-1942. Burkart et al. s.n. (LIL, SI). Vega del Azufre. 15-I-1941. Castellanos s.n. (LIL). Valle Hermoso, 2800 m. 19-II-1974. Fiedler 98 (SI). Valle Hermoso. I-1897. Stuckert 3017 (CORD). Valle de Las Leñas. 25-XII1989. Kiesling \& Donath 7265 (SI). Portezuelo del Choique, $36^{\circ} 22^{\prime} 38^{\prime \prime} \mathrm{S}, 6^{\circ} 48^{\prime} 21^{\prime \prime} \mathrm{W}, 23-\mathrm{XI}-2001$. Prina et al. 1399 (SI). Sobre la ruta 40 vieja, 36²2'38"S, $6^{\circ} 45^{\prime} 47^{\prime \prime} \mathrm{W}, 2550 \mathrm{~m} .14-\mathrm{XII}-2001$. Prina et al. 1547 (SI). Alto Valle del Atuel, Quebrada Nield. 9-17-I-1954. Roig 254 (MERL). Quebrada del A Nield, 2800-2900 m. 917-I-1954. Ruiz Leal \& Roig 15793 (MERL). Depto. San Carlos, Frente al volcán Maipo, 3500 m, I-1921, Carette 396 (SI). Depto. San Rafael, Distrito El Sosneado: Alto Valle del Atuel, entre Sominar y Laguna Atuel, $2800 \mathrm{~m}$. 6-7-II-1955. Ruiz Leal 16796 (MERL). Depto. Tunuyán, Valle del Alto Tunuyán: Las Salinillas, cerca del cerro Marmolejo. 1-II-1934. Ruiz Leal 2068 (MERL). Prov. Neuquén. 1-II-1900. Asp 1010 (SI). Dpto. Ñorquin, C Huaile, ladera NO, 37 $04^{\prime} 22^{\prime \prime} \mathrm{S}, 70^{\circ} 07^{\prime} 14^{\prime \prime} \mathrm{W}, 2550 \mathrm{~m}$. 8I-2001. Biganzoli 1193 (SI). Dpto. Huiliches, Estancia
"Las Breñas", de Mallín Escondido a Paso Cerrado,

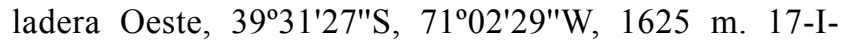
2001. Biganzoli 1211 (SI). Depto. Minas, Lagunas EpuLauquén, pedregales próximos al $\mathrm{A}^{\circ}$ Pincheira, $36^{\circ} 50^{\prime} \mathrm{S}$, $71^{\circ} 03^{\prime} \mathrm{W}, 1300 \mathrm{~m} .18-\mathrm{I}-1964$. Boelcke et al. 11006 (SI). Cajón del Portillo, 36 ${ }^{\circ} 12^{\prime} \mathrm{S}, 70^{\circ} 36^{\prime} \mathrm{W}, 2560$ m. 31-I-1970. Boelcke et al. 14163 (SI). Reserva Prov. "Domuyo", camino geotérmico al sur de Aguas Calientes, río Covunco, comienzo de la picada sur al Domuyo, 24002600 m. 27-I-2001. Ezcurra 3113 (SI). Depto. Los Lagos, sobre la Ruta Prov. 63, cerca del Paso Córdoba, $1200 \mathrm{~m}$. 30-I-1997. Chiapella et al. s.n. (SI). Depto. Loncopué, Chenque Pehuen. 14-I-1965. Schajovskoy 131/IV (SI). Prov. Río Negro. Depto. Bariloche, Nireco, 1100 m. 7XII-1941. Neumeyer 544 (SI). Prov. Santa Cruz. Depto. Lago Argentino, Centinela, 50 $45^{\prime} \mathrm{S}, 7^{\circ} 30^{\prime} \mathrm{W}$. 24-II-1968. Anliot 6177 (SGO). Depto. Lago Buenos Aires, Ruta Nac. 40, 8,4 km al S de Estancia "Telken", 46 $52^{\prime} 01^{\prime \prime S}$, 7004'58"W, 619 m. 9-I-2008. Paiaro s.n. (SI). CHILE. Región de Valparaíso. Prov. Los Andes, Cerca de Río Blanco, camino a 3 Lagunas, $2800 \mathrm{~m}$. 15-IV-1973. Zöllner 6630 (CTES). $15 \mathrm{~km} \mathrm{~W}$ of Portillo, between Portillo and Juncal, at roadside, $2550 \mathrm{~m}$. 17-XI-1991. Eggli \& Leuenberger 1681 (SGO). Caracoles F.C.T.C. 3I-1931. King 413 (BAB). Cordillera Río Blanco, Cajón de Los Hornillos y Cajón del León. I-1936. Mandujano s.n. (SGO). Región Metropolitana. Prov. Santiago, Río Yeso, Lag. Piuquenes, 2500 m. 13-I-1945. Biese s.n. (LIL). Lag. Negro, 2700 m. 13-I-1945. Biese s.n. (LIL). Fierro Carrera, valle de San Francisco (Cordillera de Las Condes). 28-I-1930. Looser 1176 (SI). Cerca de La Parva, 3000 m. 6-I-1979. Muñoz-S. \& Meza-P. 1332 (SGO). Cerca de La Parva, 3000 m. 6-I-1979. MuñozS. \& Meza-P. 1346 (SGO). Prov. Cordillera, dpto. de Puente Alto, Comuna de San José de Maipo, Valle del Yeso, Ladera SO del embalse, 2600 m. 7-I-1970. Vargas \& Farah 46 (SGO). Cordillera, Cajón del Maipo, Baños Colina, 2400 m. 30-XII-1986. Solervicens s.n. (SGO). Cajón del Maipo, Hito Paso Internacional Maipo, 3325 m. 17-II-1995. Villagrán et al. 8461 (SGO). Región del Maule. Prov. Linares, Termas de Longaví, Laguna de los Huesos. 17-I-1938. Castellanos 21678 (SGO). Prov. Talca, por Ruta Nac. 115 , a ca. $3 \mathrm{~km}$ de la Laguna de Maule viniendo desde San Clemente, 36 $36^{\circ} 00^{\prime} 23^{\prime \prime} \mathrm{S}, 70^{\circ} 33^{\prime} 36^{\prime \prime} \mathrm{W}$, 2171 m. 9-II-2007. Chiapella et al. 1668 (SI). Laguna del Maule, 36 $01^{\circ} \mathrm{S}, 70^{\circ} 33^{\prime} \mathrm{W}, 2250 \mathrm{~m}$. 25-I-1990. Gardner et al. 4559 (SGO). Cuesta de las Arenas, Andes. II-1879. F. Philippi 1010-d (SGO). Cuesta de las Arenas. 15-II-1879. Sine collector (SI 12725). Prov. Curicó, Andes de Curicó, $\mathrm{A}^{\circ}$ de Curicó, 2000 m. 20-II-1902. Ravena s.n. (SI). Cord. de Peteroa, 1891, Vidal s.n. (SGO). Andes prov. Curicó, 1.d. Baños. 1889-1890. Vidal s.n. (SGO). Región de Magallanes. Prov. Tierra del Fuego, Bahía Inútil, 150 m. XI-1930. Donat s.n. (LIL). 
6. Nastanthus ventosus (Meyen) Miers, Ann. Mag. Nat. Hist. ser. 3, 6: 188, 1860. Calycera ventosa Meyen, Reise um die Erde 1: 356, 1834. Boopis scapigera J.Remy var. ventosa (Meyen) Weddell, Chl. And. 2: 7, 1858. Nastanthus caespitosus (Phil.) Reiche var. ventosus (Meyen) Pontiroli, Revista Mus. La Plata, Secc. Bot. 9(41): 233. 1963. TYPE: Chile. "Rio del Volcan [...] Am Ende des Thales hatten wir die Schneegrenze erreicht". Meyen s.n. (holotype $\mathrm{B} \dagger$, lectotype, here designated, H. A. Weddell, Chloris Andina 2: Planche 44A(1-6). 1857[1858]). Fig. 7.
Boopis gayana Phil., Linnaea 28: 709, 1856. Nastanthus gayanus (Phil.) Miers, Ann. Mag. Nat. Hist. ser. 3, 6: 189, 1860. Nastanthus agglomeratus Miers var. gayanus (Phil.) Reiche, Anales Univ. Chile 106: 1030, 1900. TYPE: Chile. "In Andibus prov. Arauco ad Santa Barbara". XII-1838. Gay 1491 (holotype SGO-057223, photo SI!).

Nastanthus agglomeratus Miers, Ann. Mag. Nat. Hist. ser. 3, 6: 186, 1860. Boopis (Nastanthus) agglomeratus (Miers) Hauman, An. Soc. Cient. Arg. 85: 311, 1918. Calycera andina Miers, Trav. Chil. 2: 531, 1826, nom.

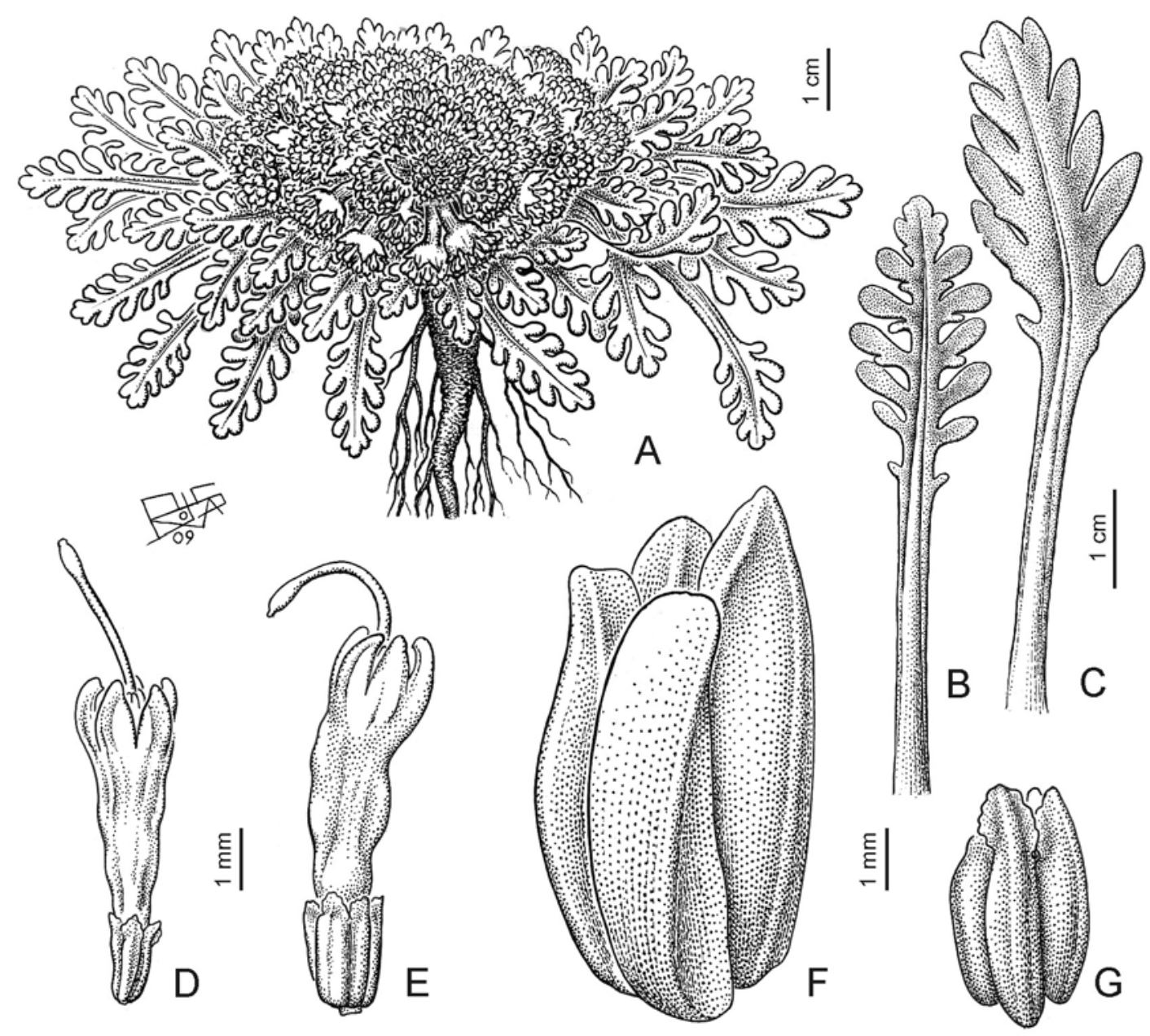

Figure 7. Nastanthus ventosus. A. Habit. B-C. Leaf variation. D. Flower at pistillate phase. E. Young fruit, corolla whithered. F-G. Fruit variation. A, B, D, E, drawn from F. Roig s.n. (MERL-18719); C, G, from A. Ruiz Leal 23417 (MERL); F, from A. Ruiz Leal 6611 (MERL).

Figura 7. Nastanthus ventosus. A. Hábito. B-C. Variación foliar. D. Flor en fase pistilada. E. Fruto inmaduro, corola marchita. F-G. Variación del fruto. A, B, D, E, dibujado de F. Roig s.n. (MERL-18719); C, G, de A. Ruiz Leal 23417 (MERL); F, de A. Ruiz Leal 6611 (MERL). 
nud. Nastanthus andina (Miers) H.V. Hansen, Nordic J. Bot. 12 (1): 65, 1992, nom. inval. TYPE: Chile. Near the Cumbre on the descent to Las Cuevas elevation of 11500 feet above the level of the sea. Cordillera of Chile. I1825. Gillies s.n. (holotype BM-000947740, photo SI!; isotypes K-000009723, photo SI!, E-00259114, photo SI!).

Nastanthus pinnatifidus Miers, Ann. Mag. Nat. Hist. ser. 3, 6: 187, 1860. Nastanthus agglomeratus Miers var. pinnatifidus (Miers) Reiche, Anales Univ. Chile 106: 1030, 1900. Boopis (Nastanthus) agglomerata (Miers) Hauman var. pinnatifidus (Miers) Hauman, An. Soc. Cient. Arg. 85: 312, 1918. TYPE: Chile. "In Andibus Chilensibus". 1831. Cuming 325 (lectotype, here designated, K-000009718, photo SI!; isotypes E00259115, photo SI!, E-00259117, photo SI!).

Nastanthus gilliesii Miers, Ann. Mag. Nat. Hist. ser. 3, 6: 188, 1860. Nastanthus agglomeratus Miers var. gilliesii (Miers) Reiche, Anales Univ. Chile 106: 1030, 1900. TYPE: Chile. "In Andibus Chilensibus, Los Palomares". Gillies s.n. (holotype K-000009723, photo SI!).

Boopis (Nastanthus) sanjuanina Hieron., Bol. Acad. Nac. Cs. Cba. 4(1): 31, 1881. Boopis (Nastanthus) agglomerata (Miers) Hauman var. sanjuanina (Hieron.) Hauman, An. Soc. Cient. Arg. 85: 312, 1918. TYPE: Argentina. "Arroyo de la Ciénaga del Medio cerca del Leoncito". I-1876. Echegaray s.n. (holotype CORD!).

Boopis breviflora Phil., Anales Univ. Chile 85: 814, 1894. Nastanthus agglomeratus Miers var. breviflorus (Phil.) Reiche, Anales Univ. Chile 106: 1031, 1900. TYPE: Chile. "Coquimbo: In Andibus Illapelinis 1. d. La Polcura". I-1888. F. Philippi 2320 (lectotype, here designated, SGO-043591, photo SI!, isotypes: SGO057222, photo SI!, SI-12637!).

Boopis oocaulis Kuntze, Revis. Gen. Pl. 3(3): 127, 1898. TYPE: Argentina. "Cordillera de Mendoza: Paso Cruz", 2800 m. I-1892. Kuntze 107 (holotype, probable NY, not located; isotype SI-070776!).

Perennial, rosulate herb about $2.5-10 \mathrm{~cm}$ tall and $5-20 \mathrm{~cm}$ in diam., with a central short stem. Leaves partially fleshy, spatulate, 3-12 cm long, apex obtuse, base attenuate into a petiole of 2-3 x $1 \mathrm{~cm}$; blade pinnatifid, 1-6 x 1-3 cm, lobes obtuse to lanceolate. Peduncles many, crowded, shorter than the leaves, compressed, fleshy, bearing one terminal head each. Involucre with 8-12 wide triangular lobules of $0.2-1 \mathrm{x}$ $0.3-0.5 \mathrm{~cm}$. Receptacle convex, $0.5-3 \mathrm{~cm}$ in diam., accrescent during fruit ripening. Palea absent, or 1-2 minute, filiform, at most $0.5 \mathrm{~mm}$ long in receptacles with fruits. Flowers 20150 per inflorescence. Calyx with open or valvate aestivation, sepals 5, triangular, obtuse, emarginate, $0.3-0.4 \times 0.4-0.5 \mathrm{~mm}$. Corolla infundibuliform, tube $2.35 \times 0.9 \mathrm{~mm}$, limb $2 \times 1.5$ $\mathrm{mm}$; lobes triangular, uncinate, $1 \times 0.7-1 \mathrm{~mm}$, aestivation valvate. Staminal tube $2.5 \mathrm{~mm}$ long, inserted at the upper third of the corolla tube, with 5 oblong nectarial glands $0.5 \mathrm{x}$ $0.2 \mathrm{~mm}$, of median position; with apical free filaments of 0.3 $\mathrm{mm}$. Anthers $1.3 \mathrm{~mm}$ long. Style exserted, $5 \mathrm{~mm}$ (staminate phase) to $7 \mathrm{~mm}$ (pistillate phase). Ovary cylindrical, 2-2.5 x $1.2 \mathrm{~mm}$. Achenes prismatic, 5-ridged, 2-8.5 x 2-4 mm, conical apiculum absent to $0.5 \mathrm{~mm}$ long, and crowned by the persistent sepals, $1-2.5 \times 0.5-1.5 \mathrm{~mm}$, continuous to the longitudinal ridges. Seed 1.25-4 x 0.2-0.8 mm.

Distribution. Andes of Chile and Argentina, between $27^{\circ}$ $37^{\circ} \mathrm{S}$, also occurring near the Pacific coast in Chile and in Cerro Nevado, Mendoza province, Argentina (Fig. 1).

Etymology. The specific epithet, ventosus, is a Latin term which has many meanings, all of them related to the wind and its attributes. In this case, it may refer to the kind of environment in which the species occurs (ventosus= windy), or the wide morphological variability which characterizes this species (ventosus $=$ fickle, changeable). It may also denote the intensely aggregated arrangement of inflorescences (ventosus $=$ puffed up).

Plants usually produce many scapiform peduncles aggregated into a hemispherical, caespitose mass (Pontiroli 1963), resembling the general shape of a cauliflower (Reiche 1900). Condensed or lax forms may be observed under different environmental conditions along its Andean distribution. The nectarial glands are more evident during the staminate phase. Flowers are green in the corolla tube and white at the limb.

Miers (1860-1869) considered Calycera ventosa Meyen underNastanthus andestablished the combinationNastanthus ventosus (Meyen) Miers. Nevertheless, Calycera ventosa was usually considered as a synonym of Boopis scapigera J.Remy since Weddell (1857), and later as Nastanthus scapigerus (J.Remy) Miers by Reiche (1900, 1901), Hicken (1919), Chiapella (1999a) and Zanotti \& Pozner (2008). The study of the type material of both Calycera ventosa and Boopis scapigera provides the separation of the former species by its smaller sepals, pinnatifid leaves, and many condensed inflorescences (see also Remy, 1847[1848]). In addition, the analyses of numerous herbarium specimens corresponding to Nastanthus agglomeratus and the type material of Calycera ventosa revealed that they share mostly the same characters on reproductive structures, and that Calycera ventosa can be placed within the morphological variation considered for $N$. agglomeratus, differing only by its longer and less condensed peduncles. Therefore, we consider both taxa as conspecific, and the earliest correct name is Nastanthus ventosus (Meyen) Miers.

The holotype of Calycera ventosa Meyen, presumably housed at $\mathrm{B}$, and the complete Meyen collection, were destroyed. All herbaria where Meyen specimens could be conserved (BR, CAS, CGE, K, L and P; Stafleu \& Cowan, 
1988) were consulted but no isotype of Calycera ventosa was found. Meyen (1834) did not cite paratypes either. Therefore, Weddell's illustration is chosen as lectotype since evidence suggests it was based on Meyen's original material: "The drawings (probably based in part on sketches by Weddell) are by Alfred Riocreux ..." (Stafleu \& Cowan, 1988, vol. 7, p. 140), and Reiche (1900: 1031) stated: "La figura de Weddell se estableció sobre una muestra original".

The specimen Gillies s.n. from BM is considered as the holotype of $N$. agglomeratus, since it has Miers' original labels. It is worth mentioning that isotypes of $N$. agglomeratus (Gillies s.n.), N. laciniatus (Cuming 326) and $N$. pinnatifidus (Cuming 325) are mounted on the same herbarium sheet at $\mathrm{E}$, but labels have been mismatched to specimens. This becomes evident when comparing isotypes from $\mathrm{E}$, types from $\mathrm{K}$ and $\mathrm{BM}$, illustrations and protologues (Miers, 1860-1869). We concluded that the specimen of $N$. laciniatus is associated with Cuming 325 (E-00259116) label (see synonymy of $N$. scapigerus below), the specimen of $N$. pinnatifidus with Gillies s.n. (E-00259115) label (see synonymy of $N$. ventosus above) and the specimen of $N$. agglomeratus with Cuming 326 (E-00259114) label (see synonymy of $N$. ventosus above). Furthermore, mistakes have been repeated in another two sheets from E, where a specimen of $N$. pinnatifidus is labeled as Cuming 326 (E00259117), and a specimen of $N$. laciniatus is labeled as Cuming 325 (E-00259118).

Nastanthus agglomeratus var. pinnatifidus is not considered here as a good variety because the foliar morphology of $N$. ventosus includes characters used to define the variety. The specimen Cuming 325 is chosen as lectotype since it better describes the plant morphology and it is better conserved than the syntype Gay s.n. from "Cordillera de Coquimbo"; the later is fragmented and poorly preserved.

The remaining varieties of $N$. agglomeratus $(N$. agglomeratus var. gayanus, $N$. agglomeratus var. gilliesii and $N$. agglomeratus var. breviflorus) were previously considered as synonyms of $N$. agglomeratus by Zanotti \& Pozner (2008). About Boopis breviflora, the specimen SGO-043591 is chosen as lectotype since it has better conserved material and greater number of flowers and fruits than SGO-057222.

The holotype of Boopis oocaulis is probably housed at NY (Zanoni 1982, O'Leary 2006). The isotype possesses short blades, consisting of five small lobules, few-flowered inflorescences of 20-30 flowers, flowers with a short corolla tube with abbreviated whitish lobules, closely matching $N$. ventosus. Differences with $N$. ventosus (more flowers per inflorescence and leaves with more than 5 lobules) may be caused by environmental conditions such as soil development and water availability. Besides, B. oocaulis is known only from the type material, and other authors
(Pontiroli 1963) have pointed out the doubtful validity of this taxon.

The type specimen of Boopis sanjuanina can be placed confidently within the morphological variation of Nastanthus ventosus; even Hieronymus (1881) remarked about his uncertainty when creating the species. Moreover, Pontiroli (1963) confused $N$. agglomeratus with $N$. caespitosus and erroneously cited Boopis sanjuanina in synonymy to the later species.

The comparison between $N$. ventosus and related taxa, here treated as synonyms, shows that vegetative morphological characters vary, whereas the reproductive ones (floral characters) remain constant (Table II).

\section{SPECIMENS EXAMINED}

ARGENTINA. Prov. La Rioja. Depto. Vinchina, Entre Jagüé y Salina del Leoncito, a $61 \mathrm{~km}$ del primero, $11 \mathrm{~km}$ al oeste de la Puerta de la Quebrada del Leoncito, 3400 m. 7-II-1998. Biurrun et al. 5171 (CTES). "Reserva Laguna Brava", Laguna Brava, costa oeste de la laguna, 2816'21"S, 6849'50"W, $4281 \mathrm{~m}$. 8-I-2009. Donadío et al. 75 (SI). Depto. Gral. Ángel V. Peñaloza, Vegas de Descubrimiento Viejo, 3000 m. 22-XI-1915. Hosseus 1534 (CORD). Prov. San Juan. Depto. Iglesia, Reserva de San Guillermo, Nacimiento del Río La Sal: Rincón de las Flechas, 3900 m. 4-I-1984. Beorchia 6 (SI). De la Laguna del Macho Muerto a Las Caranchas, 3700-4200 m. 22-II1984. Kiesling 4622 (SI). Llanos de San Guillermo, 3300 m. 10-I-1997. Kiesling et al. 8783 (SI). Cerca de San Guillermito, Bajada la Olorosa, 3650 m. 2-I-1984. Meglioli 11 (SI). Mina Las Carachas, 4050 m. 20-I-1981. Nicora et al. 8228 (SI). Río Macho Muerto, refugio de Macho Muerto, 4030 m. 14-I-1983. Nicora et al. 8498 (SI). Río Macho Muerto, a más o menos $7 \mathrm{~km}$ del refugio. 14-I-1983. Nicora et al. 8507 (SI). Refugio del Macho Muerto, 4050 m. 13-XII-1981. Pujalte 42 (SI). Veguita en la cordillera de San Guillermo, 4100 m. 17-XII-1982. Pujalte 168 (SI). Quebrada del Agua Negra, 4000 m. 21-II-1979. Cabrera 30079 (SI). Quebrada del Agua Negra, 3800 m. 10-XII1979. Cabrera et al. 31124 (SI). Quebrada del Agua Negra. 15-II-1986. Kiesling et al. 6188 (SI). A $10 \mathrm{~km}$ al Oeste del Portezuelo de Conconta, 29 $57^{\prime} 49^{\prime \prime} \mathrm{S}, 6^{\circ} 43^{\prime} 05^{\prime \prime} \mathrm{W}, 4052 \mathrm{~m}$. 22-II-1998. Herrera \& Jiménez 865 (SI). Cerca del Paso del Agua Negra, entre Arrequintín y el límite con Chile, ca. Km 125/130, 3700 m. 28-II-1983. A. T. Hunziker \& Subils 24580 (CORD). Valle del Cura, Alojo Los Catres, 3850 m. 23-I-1981. Kiesling 3194 (SI). Valle del Cura, 4000 m. 26-XI-1980. Múlgura \& Deginani 165 (SI). Zona del río Las Taguas, Quebrada Potrerillos, $29^{\circ} 21^{\prime} \mathrm{S}, 6^{\circ} 58^{\prime} \mathrm{W}$, 3700 m. 1-II-2000. Teillier \& Márquez 4496 (SI). Depto. Ullum, del refugio de la Estancia "Don Carmelo" hacia el $\mathrm{S}$, entre las Sierras de la Invernada y del Tigre, $30^{\circ} 58^{\prime} 39^{\prime \prime} \mathrm{S}$, $69^{\circ} 05^{\prime} 13 " \mathrm{~W}, 3100 \mathrm{~m}$. 9-II-2000. Kiesling et al. 9407 (SI). Depto. Calingasta, Reserva Natural Estricta "El Leoncito", 
Ciénaga de las Cabeceras. 22-I-1995. Apochian et al. 175 (SI). Ciénaga Las Cabeceras, 2780 m. 14-I-1995. Kiesling et al. 8579 (SI). Quebrada del $\mathrm{A}^{\circ}$ de las Cabeceras, 3000 m. 19-XI-1997. Haene et al. 1778 (SI). Quebrada Arroyo Portezuelo, 3730 m. 9-IV-1999. Haene 1995 (SI). Estancia "El Leoncito", Ciénaga de las Cabeceras, 2730 m. 8-I-1993. Haene 1164 (SI). Sierra del Tontal, $C^{\circ}$ Casa de Piedra, 3400 m. 20-II-1984. Kiesling 4529 (SI). Sierra del Tontal, 2800 m. 22-I-1987. Kiesling \& Meglioli 6518 (SI). Cordillera de Ansilta, Quebrada del Fierro, 3900-4000 m. 20-II-1988. Kiesling et al. 6930 (SI). Oeste de Barreal: El Pachón: laguna, 3800 m. 9-15-II-1977. Kiesling \& Sáenz 1317 (SI). El Pachón: casilla Naranja. 9-15-II-1977. Kiesling \& Sáenz 1447 (MERL, SI). Laguna Pachón y Laguna Pachón Alta, 3610 m. 28-II-1975. Luti \& Barrera 5482 (CORD). Yunque, entre El Molle y Erizos, camino de Barreal a Pachón, 3100 m. 9-I-1976. Luti et al. 5547 (CORD). Arroyo Blanco, 3950 m. 19-31-I-1950. Roig 12179 (MERL). Cordillera del Espinacito, Los Portillos, 3435 m. 10-II-1897. Kurtz 9678 (SI). Prov. Mendoza. Depto. Las Heras, Puente del Inca, faldeo S, C ${ }^{\circ}$ Banderita Norte, 3150 m. 12-I-1973. Boelcke et al. 9808 (BAB, SI). Puente del Inca. Sine data. Autran 61 (SI). C $C^{\circ}$ Banderita sur. 11-II-1940. Ruiz Leal 6611 (MERL). Puente del Inca. III-1901. C. Spegazzini 959 (BAB, SI). Puente del Inca. III-1908. C. Spegazzini 24360 (SI). Laguna Los Horcones, 2800 m. 27-III-1954. J. H. Hunziker 6340 (BAB). Ladera limoso-pedregosa ca. Río Los Horcones, 3030 m. 16-I-1985. J. H. Hunziker et al. 11160 (SI). Alrededores Laguna, 3180 m. 16-I-1985. J. H. Hunziker et al. 11173 (SI). Laguna de Los Horcones. 14-XII1964. Ruiz Leal 23417 (MERL). Laguna de Los Horcones. 10-II-1908. C. Spegazzini s.n. (BAB). Sierra de Bonilla. IV-1906. Looser 15014 (SI). Pampa de Canota, 3000 m. 20XII-1982. Martínez-Carretero s.n. (MERL). Precordillera: Agua de las Cerrajas. 22-XI-1957. Roig s.n. (MERL). C ${ }^{\circ}$ El Platita, 4150 m. 21-I-1983. Roig 11055 (MERL). Sierra de Uspallata: El Jagüel. 9-II-1982. Roig 10822 (MERL). Paramillo de Uspallata: Pampa Fría. 5-IV-1967. Ruiz Leal 25260 (MERL). Las Cuevas. 8-VIII-1901. C. Spegazzini 1009 (SI). Quebrada de Matienzo, 3510 m. 30-I-1980. Wingenroth 30 (SI). Quebrada de Matienzo. 14-II-1981. Wingenroth 90 (SI). Depto. Luján de Cuyo, Río Mendoza, Altas Cordilleras de Mendoza, 2700-3500 m. 20-I-1908. Hauman-Merck 114 (SI). Vallecitos cerca del refugio Club Regatas Mendoza, 32 $58^{\prime} 48,3^{\prime \prime} \mathrm{S}, 69^{\circ} 21^{\prime} 19,8^{\prime \prime} \mathrm{W}, 3020 \mathrm{~m}$. 11-I-2003. A. Cocucci et al. 2218 (CORD, SI). Quebrada del Rincón de los Vallecitos, 3700 m. 21-24-I-1939. Vadés s.n. (MERL). Depto. San Carlos, Laguna del Diamante,
3300 m. 28-I-1950. Balegno \& Palacios s.n. (LIL). Laguna del Diamante, 3200 m. 20-I-1941. Ruiz Leal 7236 (MERL). Laguna del Diamante. 3-II-1950. Soriano 4106 (SI). Ruta 98, Pampa de los Avestruces, 3780 m. 25-I-1985. J. H. Hunziker et al. 11307 (MERL, SI). Inmediaciones de las vegas del Llaucha. II-1942. Patiño s.n. (MERL). Estancia "Llaucha": A ${ }^{\circ}$ de Los Leones, 3200 m. 16-I-1949. Ruiz Leal 11760 (MERL). Arroyo de los Gauchos y Pampa de los Avestruces, 3370 m. 20-I-1965. Ruiz Leal 23507 (MERL). Entre la aduana y Potrero de los Zorros. 16-I-1965. Ruiz Leal 23609 (MERL). Depto. San Rafael, Cajón del Burro. II-1913. Gerth 120 (SI). El Ángulo - El Sosneado. 19-I1993. H. A. L. 8393 (SI). Distrito Cuadro Benegas: El Ángulo. Nacientes del A ${ }^{\circ}$ Las Yeseras, 3020 m. 16-II-1984. Méndez \& Wuilloud s.n. (MERL). Depto. Malargüe, Baños del Azufre. 19-I-1941. Castellanos s.n. (LIL). Sierra del Nevado, lomas al SSE expuesta al S, 2450-2500 m. 22-I1974. Boelcke et al. 15918 (BAB). C $^{\circ}$ Nevado, 35 35'43"S, 6830'21"W, 3055 m. 14-XII-2005. Prina et al. 2938 (SI). Portezuelo Ancho, 2900 m. 8-XII-1985. H. A. L. 7008 (SI). Cord. de Mendoza (Río Salado sup.): Cerro de Los Molles, 3000 m. 8-I-1890. Kurtz 7513 (SI). Los Molles, arriba del "Cuchillo", 2600 m. 31-XII-1949. Sleumer s.n. (LIL). Prov. Neuquén. Depto. Minas, Sierra de Cochicó, cumbre, $36^{\circ} 18^{\prime} \mathrm{S}, 70^{\circ} 30^{\prime} \mathrm{W}, 2500-2700 \mathrm{~m}$. 29-I-1970. Boelcke et al. 14066 (BAB, SI). La Corona, Cordillera del Viento. 6-IV1912. Pastore 96 (SI). CHILE. Región de Atacama. Prov. Copiapó, Cord. Río Turbio, Co. Cadillal, 3500 m. I-1926. Werdermann 946 (LIL, SI). Laguna Negro Francisco, $27^{\circ} 27^{\prime} \mathrm{S}, 69^{\circ} 13^{\prime} \mathrm{W}, 4150 \mathrm{~m}$. 1-II-1997. Teillier 4183 (SGO). Laguna Negro Francisco, Agua Dulce. 20-III-1993. TorresMura s.n. (SGO). Pastos Largos. 5-I-1885. F. Philippi s.n. (SI). Región de Valparaíso. Prov. Los Andes, Laguna del Inca. 29-I-1886. Kurtz s.n. (SI). Región Metropolitana. Prov. Cordillera, Nacimientos del Maipo, 3100 m. I-1921. Carette 68 (SI).

\section{DoubTFUl NAMES}

Boopis acaulis Phil., Anales Univ. Chile 18: 49, 1861. Nastanthus acaulis (Phil.) Reiche, Anales Univ. Chile 106: 1032, 1900. TYPE: Chile. "Huanta". Volckmann s.n. (holotype SGO-057220, photo SI!).

We have only seen a digital image of the holotype, and the specimen is so depauperate, poorly preserved and folded that its morphology can hardly be evaluated. Although some features resemble $N$. ventosus, the decision about its synonymy is postponed until an examination of the type material can be made. 

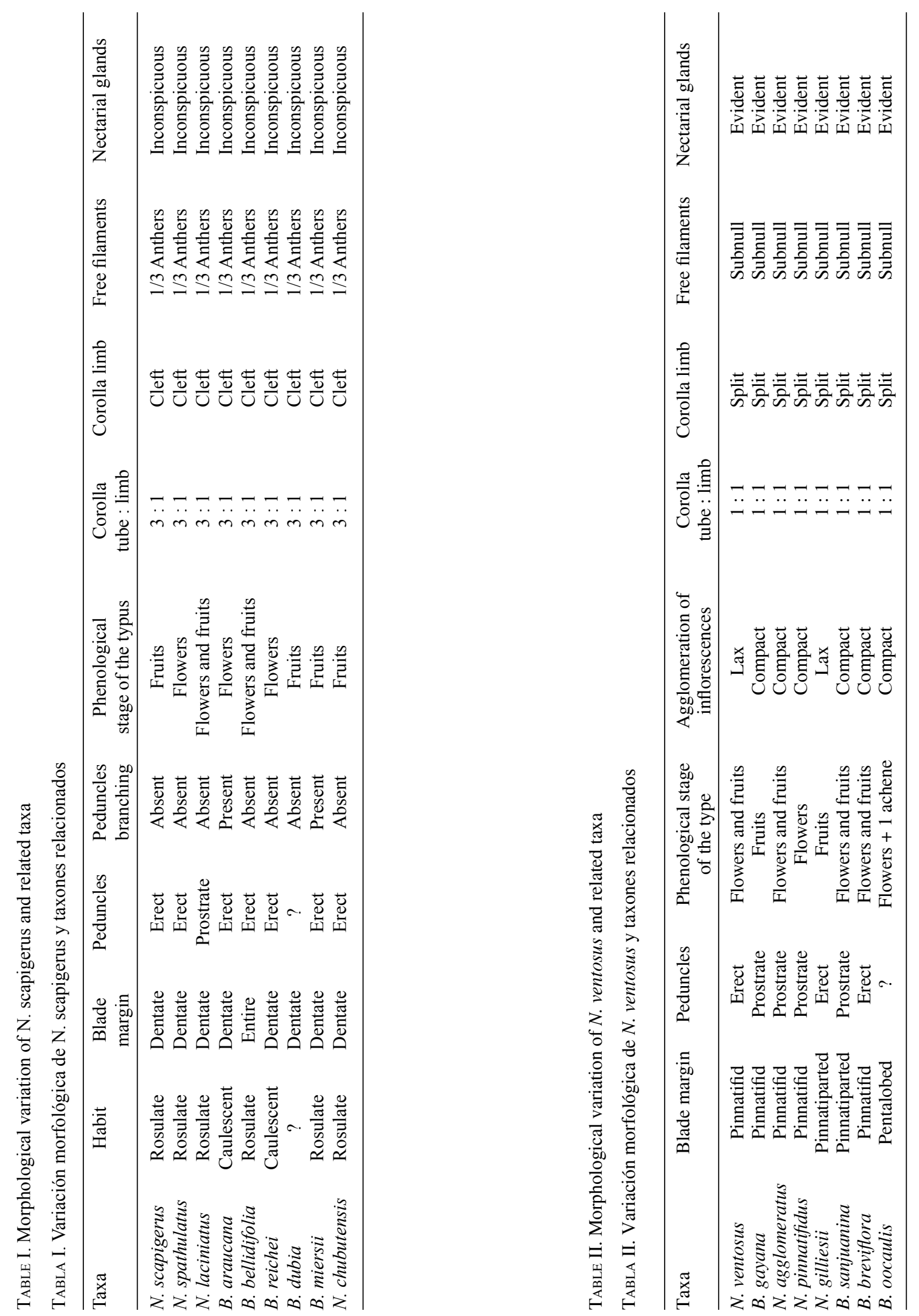


\section{CONCLUSIONS}

Based on our results, Nastanthus includes six species: $N$. caespitosus, $N$. compactus, $N$. falklandicus, $N$. patagonicus, $N$. scapigerus, and $N$. ventosus. Five species and three variety names, up to date in use, are newly placed into synonymy ( $N$. agglomeratus, $N$. spathulatus, $N$. chubutensis, $N$. araucanus, $N$. diazi, N. agglomeratus var. pinnatifidus, $N$. agglomeratus var. laciniatus, and N. spathulatus var. bellidifolius).

\section{ACKNOWLEDGEMENTS}

We thank curators of the following herbaria: $\mathrm{BAB}, \mathrm{CORD}$, CTES, E, GH, K, LIL, LP, MERL, P, RNG, S, SGO, SI and $\mathrm{W}$, for type material and digital images; Francisco Rojas for the illustrations of $N$. ventosus, $N$. caespitosus, $N$. compactus; and Natalia Álvarez for the digital images of type material housed in SGO. This research was supported by the "Cristóbal M. Hicken" fellowship (Academia Nacional de Ciencias Exactas, Físicas y Naturales, Argentina), and the project "Speciation in Patagonia: establishing sustainable international collaborations in evolution, ecology and conservation biology", NSF OISE-0530267.

\section{LITERATURE CITED}

BALL, J. 1886 [1884]. Contributions to the Flora of North Patagonia and the adjoining Territory. The Journal of the Linnean Society, Botany 21: 203-240.

Cabrera, A. L. \& A. Willink. 1980. Biogeografía de América Latina, ed. 2. Serie de Biología. Monografía $n^{\circ} 13$. Secretaría General de la Organización de los Estados Americanos. Programa Regional de Desarrollo Científico y Tecnológico, Washington. 122 pp.

Carlquist, S. \& M. DeVore. 1998. Wood anatomy of Calyceraceae with reference to ecology, habit, and systematic relationships. Aliso 17(1): 63-76.

Chiapella, J. 1999a. Calyceraceae. En: M.N. Correa (ed.), Flora patagónica. Ericaceae a Calyceraceae, Tomo 8, Parte 6, pp. 492-517. Colección Científica del INTA, Buenos Aires, Argentina.

Chiapella, J. 1999b. Calyceraceae. En: F.O. Zuloaga \& O. Morrone (eds.), Catálogo de las Plantas Vasculares de la República Argentina. Monographs in Systematic Botany from the Missouri Botanical Garden 74: 490-495.

Erbar, C. \& P. Leins. 1995. Portioned pollen release and the syndromes of secondary pollen presentation in the Campanulales-Asterales-complex. Flora 190: 323-338.

Galvão Magenta, M.A. \& J.R. PiRAni. 2002. Calyceraceae. Flora Fanerogamica do Estado de São Paulo 67-69.

HANSEN, H.V. 1992. Studies in the Calyceraceae with a discussion of its relationship to Compositae. Nordic J. Bot. 12(1): 63-75.

Hellwig, F.H. 2007. Calyceraceae. In: K. Kubitzki, J.W. Kadereit \& C. Jeffrey (eds.), The families and genera of vascular plants. Flowering plants - Eudicots. Asterales, Vol. 8, pp. 19-25. Springer-Verlag Berlin Heidelberg, Berlin, Germany.
Hicken, C.M. 1919. Calyceracearum Argentinarum Catalogus. Catálogo de las caliceráceas argentinas. Reunión Nacional de la Sociedad Argentina de Ciencias Naturales - Tucumán 1916, 1: 238-253.

Hieronymus, G.H.E.W. 1881. Sertum Sanjuaninum ó descripciones y determinaciones de plantas fanerógamas y criptógamas vasculares recolectadas por el Dr. D. Saile Echegaray en la Provincia de San Juan. Boletín de la Academia Nacional de Ciencias en Córdoba 4(1): 1-73.

Holmgren, P.K., N.H. Holmgren \& L.C. Barnett. 1990. Index herbariorum. Part I: The herbaria of the world. 8th edition. New York Botanical Garden, New York. 693 pp.

MeYen, F. J.F. 1834. Reise um die Erde ausgefürt auf them Königlich preussischen Seehandlungs-Schiffe Prinzess Louise, commandirt von Capitain W. Wendt, in den Jahren 1830, 1831 und 1832. Vol. 1, Berlin. 493 pp.

Miers, J. 1860-1869. Contributions to botany, iconographic and descriptive, detailing the characters of plants that are either new or imperfectly described; to which are added remarks on their affinities. Vol. 2. Williams \& Norgate, London. 267 pp.

Moore, D.M. 1967. Further records for the vascular flora of the Falkland Islands. Botaniska Notiser 120: 17-25.

O'Leary, N. 2006. Typifications in Verbena (Verbenaceae). Darwiniana 44(2): 493-499.

Pontiroli, A. 1963. Flora argentina. Calyceraceae. Revista del Museo de La Plata (N. S.) 9 (Bot. 41): 175-241.

Pozner, R., C. Zanotti \& L. Johnson. 2010. Evolutionary origin of the Asteraceae capitulum: insights from Calyceraceae. Southern Connection Congress, 15-19 de febrero de 2010, Bariloche, Argentina. Libro de Resúmenes: 197.

Reiche, K. 1900. Caliceráceas. Anales Universidad de Chile 106: 1027-1048.

ReICHE, K. 1901 [1900]. Beiträge zur Systematik der Calyceraceen. Botanische Jahrbücher für Systematik, Pflanzengeschichte und Pflanzengeographie 29: 107-119.

ReITZ, R. 1988. Caliceráceas. In: R. Reitz (ed.), Flora ilustrada Catarinense. I Parte. Monografia. As plantas, pp. 1-18. Herbário "Barbosa Rodrigues", Itajaí, Santa Catarina, Brasil.

RÉmy, E. J. 1847 [1848]. Calicereas. En: C. Gay (ed.), Historia física y política de Chile según documentos adquiridos en esta República durante doce años de residencia en ella. Botánica, Tomo 3, pp. 246-256. Imprenta de Fain y Thunot, Paris, Francia.

Stafleu, F.A. \& R.S. Cowan. 1988. Taxonomic Literature. A selective guide to botanical publications and collections with dates, commentaries and types. Volume VII: W-Z. $2^{\text {nd }}$ edition. Bohn, Scheltema \& Holkema, Utrecht/Antwerpen dr. W. Junk b.v., Publishers, The Hague/Boston. 653 pp.

Weddell, H.A. 1857 [1858]. Chloris Andina. Essai d'une flore de la région alpine des Cordillères de l'Amerique du Sud. Vol. 2. P. Bertrand, Paris. 361 pp.

ZANONI, T.A. 1982. Otto Kuntze, botanist. IV. Recent addition of specimens to the New York Botanical Garden Herbarium with other notes on Kuntze. Brittonia 34(3): 299

Zanotti, C.A. \& R.E. Pozner. 2007. Valor diagnóstico de la estructura del fruto de Boopis y Nastanthus (Calyceraceae). XXXI Jornadas Argentinas de Botánica. Boletín de la Sociedad Argentina de Botánica (Suplemento) 42: 142.

Zanotti, C.A. \& R.E. Pozner. 2008. Calyceraceae. En: F.O. Zuloaga, O. Morrone \& M.J. Belgrano (eds.), Catálogo de las plantas vasculares del Cono Sur. Dicotyledoneae: Acanthaceae-Fabaceae (Abarema-Schizolobium), Vol. 2, pp. 1844-1853. Monographs in Systematic Botany from the Missouri Botanical Garden, St. Louis, United States.

Recibido: 21.04 .10

Aceptado: 24.06 .10 